University of Nebraska - Lincoln

DigitalCommons@University of Nebraska - Lincoln

Faculty Publications, Department of Psychology

Psychology, Department of

$5-2018$

Four Decades of the Journal Law and Human Behavior. A Content Analysis

\author{
Lindsey E. Wylie \\ University of Nebraska at Omaha, slwylie@unomaha.edu \\ Katherine P. Hazen \\ University of Nebraska-Lincoln, katherine.hazen@unl.edu \\ Lori A. Hoetger \\ University of Nebraska-Lincoln \\ Joshua A. Haby \\ University of Nebraska-Lincoln \\ Eve M. Brank \\ University of Nebraska-Lincoln, ebrank2@unl.edu
}

Follow this and additional works at: https://digitalcommons.unl.edu/psychfacpub

Part of the Law and Psychology Commons, and the Psychology Commons

Wylie, Lindsey E.; Hazen, Katherine P.; Hoetger, Lori A.; Haby, Joshua A.; and Brank, Eve M., "Four Decades of the Journal Law and Human Behavior. A Content Analysis" (2018). Faculty Publications, Department of Psychology. 962.

https://digitalcommons.unl.edu/psychfacpub/962

This Article is brought to you for free and open access by the Psychology, Department of at DigitalCommons@University of Nebraska - Lincoln. It has been accepted for inclusion in Faculty Publications, Department of Psychology by an authorized administrator of DigitalCommons@University of Nebraska - Lincoln. 
Published in Scientometrics 115 (May 2018), pp. 655-693; doi: 10.1007/s11192-018-2685-y Copyright (C) 2018 Akadémiai Kiadó, Budapest, Hungary; published by Springer. Used by permission. Submitted April 10, 2017; published online February 26, 2018.

\title{
Four Decades of the Journal Law and Human Behavior: A Content Analysis
}

\author{
Lindsey E. Wylie, ${ }^{1}$ Katherine P. Hazen, ${ }^{2}$ Lori A. Hoetger, ${ }^{2}$ Joshua A. Haby, ${ }^{2}$ \\ and Eve M. Brank ${ }^{2}$
}

1. University of Nebraska Omaha, Omaha, Nebraska, USA

2. University of Nebraska-Lincoln, Lincoln, Nebraska, USA

Corresponding author - Lindsey E. Wylie, email slwylie@unomaha.edu

\begin{abstract}
Although still relatively young, the journal Law and Human Behavior (LHB) has amassed a publication history of more than 1300 full-length articles over four decades. Yet, no systematic analysis of the journal has been done until now. The current research coded all full-length articles to examine trends over time, predictors of the number of Google Scholar citations, and predictors of whether an article was cited by a court case. The predictors of interest included article organization, research topics, areas of law, areas of psychology, first-author gender, first-author country of institutional affiliation, and samples employed. Results revealed a vast and varied field that has shown marked diversification over the years. First authors have consistently become more diversified in both gender and country of institutional affiliation. Overall, the most common research topics were jury/judicial decision-making and eyewitness/memory, the most common legal connections were to criminal law and mental health law, and the most common psychology connection was to social-cognitive psychology. Research in psychology and law has the potential to impact both academic researchers and the legal system. Articles published in LHB appear to accomplish both.
\end{abstract}

Keywords: content analysis, Law and Human Behavior, psychology and law history, research trends 


\section{Introduction}

Most observers point to Münsterberg's (1908) On the Witness Stand: Essays on Psychology and Crime as the birth of the law-psychology discipline (Vaccaro and Hogan 2004; see, Bornstein and Penrod 2008); however, the field did not truly take root until the 1970s. Law-psychology is the study of the "contributions of psychology to the understanding of law and legal institutions through basic and applied research" (American Psychology-Law Society 2017). Late in the 1960s at an American Psychological Association (APA) annual convention, fifteen people met and discussed the intersection of psychology and law and the possibility of an organization to support this interdisciplinary work (Grisso 1991). The American Psychology-Law Society (AP-LS) met for their first conference in 1974. That same year, the University of NebraskaLincoln established the first joint JD/PhD program under the leadership of Bruce Sales (Bornstein et al. 2008).

In 1977, Sales established both a law-psychology book series and a journal, Law and Human Behavior (LHB), that were done in cooperation with AP-LS. A few years later, LHB was named the official publication of AP-LS (Grisso 1991). LHB is a multidisciplinary journal that publishes manuscripts that discuss the relationship "between human behavior and the law, the legal system, and the legal process" (APA 2017). For the first issue, Sales was joined by associate editor, Harvey Perlman, JD, who had recently left the University of Nebraska-Lincoln for the University of Virginia School of Law. The choice of a law faculty member as the associate editor reflected the composition of scholars who were affiliated with law-psychology - at the time, lawyers composed approximately $40 \%$ of the membership of AP-LS (Grisso 1991).

The current article begins with an overview of the four decades of $L H B$ history including calls for expansion of the covered topics in both breadth and depth. Next, we discuss the importance of quantitatively studying the features and characteristics of scientific research and describe previous reviews of law-psychology research, which have not exhaustively and objectively examined the totality of $L H B$ articles. We then present a comprehensive content analysis of all published LHB full articles from Volume 1 through Volume 40. Finally, we conclude with a call and encouragement for future research to push our field into new areas in the coming decades, while also continuing to study issues in depth to support the needs of courts and policy-makers.

\section{Editorial history}

At the conclusion of 2016, the journal had published 40 volumes across four decades and had six editors-in-chief. After founding editor Bruce Sales, Michael Saks took over as the second editor. Ronald Roesch was the third, Richard Wiener the fourth, and Brian Cutler the fifth. The current editor, Margaret Bull Kovera, is the first female editor-in-chief of the journal. During her first month as the editor, $L H B$ received a record number of submissions (Kovera 2013b), and the journal continues to be the top-ranked journal in its area (Kovera 2015). The journal is now published by the American Psychological Association under their Educational Publishing Foundation (EPF) imprint and has a 2.82 impact factor (APA 2017). 
Despite the journal's achievements and success, most of the editors of the journal have made a call for broadening and diversifying the field's research. After being the editor for a year and a half, Michael Saks commented on the manuscripts submitted to LHB: "I am struck by the limited range of topics they address. I want to sound a warning and extend an invitation... we have not been exploring a range of topics and issues as broad and as rich as the law offers us ..." (Saks 1986, p. 279). Two years into his editorship, Roesch (1990) endorsed Saks's sentiment and encouraged more research on "clinical forensic issues" (p. 1). Richard Wiener also called for a broadening of "the journal's interest in areas of substantive law" (p. 2). In Cutler's Editor's Note (2007) he explained that he wanted to "dispel concerns" that the reviewers and editors would be "particularly hard" on submitted manuscripts that presented research outside what he called "mainstream" topics (p. 1). Cutler went on to affirm LHB's status as an "interdisciplinary journal" and encouraged submissions from "multiple behavioral perspectives in research" (p. 1). Finally, the current editor, Kovera, made a call in the AP-LS newsletter (2013a) for "ground breaking, high-quality research at the intersection of psychology and law" and encouraged AP-LS members to reach out to scholars who are doing that kind of work (p. 13). Notwithstanding these repeated calls for more variety and diversity, there has not yet been a systematic examination of the published work in the journal.

\section{Previous reviews and current approach}

One way to systematically study a discipline's history, trends, and emphases is by analyzing published journal articles (Kim et al. 2010; Walia and Kaur 2012). Scholarly communication through academic journals not only provides useful descriptive information about a journal but can also increase understanding of the development and output of a given discipline (Godin 2006; Hérubel et al. 1999). Although others have written about the state of the field in law-psychology, prior reviews have generally taken a selective approach (Haney 1980, 1993; Tapp 1976; Monahan and Loftus 1982). That is, scholars in the field summarize the research and typically discuss, in depth, a selection of the most relevant areas at the time. Others have randomly sampled articles in $\angle H B$ from a given time period to examine the development of psychological theory (Small 1993) or done more in-depth inquiries by performing focused examinations of particular areas within law-psychology (e.g., Bornstein 1999; Devine et al. 2000; Meissner and Brigham 2001; Moore and Finn 1986). Although the selective review approach provides value because each area can be discussed in depth, an objective review that includes all possible articles from $L H B$ allows for the inclusion of systematic quantitative inquiries and offers breadth on the topic that has been lacking up to this point.

One method for describing journal trends is to objectively measure an article's impact by coding features within each article and testing whether those factors significantly predict citation impact (Haslam et al. 2008). Scientometrics is a method for analyzing publications to ascertain the impact of research articles, the evolution of a discipline (Hérubel et al. 1999), and the factors that make an article influential (Haslam et al. 2008; Sternberg and Gordeeva 1996). Analyzing $L H B$ through this lens can provide researchers with information about what kinds of articles have been most successful in garnering the attention of other scholars or the courts (see, Ogloff 2000). To date, there is no known study that has systematically examined LHB 
using methods from Scientometrics. As such, the aim of this research is twofold: (1) to provide a historical perspective on how $L H B$ publications have shifted over time and (2) to examine what factors contribute to article impact, including article structural and organizational properties, author characteristics and institutional information, research topics, research areas (i.e., connections to law and psychology), and research approach (i.e., sample information).

As noted in previous studies, the structure or organizational properties of academic articles have changed over time and influence the number of citations (Haslam et al. 2008). For instance, the use of colons in titles has increased (Lewison and Hartley 2005), which has been proposed as an indication of scholarly complexity and distinction (Dillon 1981; Haslam et al. 2008). Furthermore, the length of the article may impact how many findings are discussed (Haslam et al. 2008; Hudson 2007; Stewart 1983), and the extent of the references included both may affect subsequent citations (Adair and Vohra 2003; Haslam et al. 2008).

While early research found that author gender does influence article citations (Helmreich et al. 1980), more recent research has not found these gender differences (Barrios et al. 2013; Leimu and Koricheva 2005). Researchers may be biased to cite their own gender, and these biases may drive any observed gender differences (Ferber 1986). Within psychology more broadly, researchers have found gender authorship disparities in social psychology journals even while enrollment in PhD programs has increased for women (Cikara et al. 2012; West and Curtis 2006). It does appear, however, that within psychology journals, women's authorship has increased over time (Bailey et al. 2002; McCann et al. 2017; Porter et al. 2003). For example, in an analysis of the Journal of Marital and Family Therapy from 1990 to 2000, female first authors increased from 31 to $50 \%$ (Bailey et al. 2002).

Author nationality could also have diversified in academic journals and further predict citation impact (Haslam and Koval 2010; Leimu and Koricheva 2005). For example, in a sample of articles published in social and personality psychology journals, Haslam and Koval (2010) noted a "citation advantage" for authors from the United States, Canada, and the United Kingdom, possibly due to preferential citation, well-established research, and supportive institutions. As Ogloff (2000) noted, much of law-psychology's research has focused on issues related to American law, which does not allow comparative research for testing the validity of the principles identified. Because international collaboration in psychological science is on the rise (Kliegl and Bates 2010), non-US first authors may also be having a stronger impact. Research has found that researchers from higher-ranked universities tend to receive more citations than authors from lower-ranked universities (Leimu and Koricheva 2005), possibly because research-oriented universities have higher expectations to publish or may have more resources to engage in higher-quality research.

Furthermore, the research article content, including the research topic and the specific area of psychology or law, may shift over time and impact citation. Research on specific topics derived from certain areas of law or psychology may be more or less influential, as issues emerge within the legal system. There may also be a cyclical response to research topics and areas. That is, as a research topic becomes more established, it becomes more influential, and inspires additional work in that area. How the research is conducted-in particular the samples utilized 
to answer research questions - may influence an article's impact. For instance, the type of sample may predict citations if the sample used, for example, was more ecologically valid to the research question (e.g., criminal offenders, judges, or actual jurors) than a sample that was not ecologically valid to that research question (e.g., student samples as proxies for jurors).

Related research suggests that participant samples are becoming more diverse and that diversity of samples may influence citations. Delgado-Romero et al. (2005) examined the racial and ethnic characteristics of research participants in three counseling journals from 1990 to 1999. Overall, they found that only $57 \%$ reported racial and ethnic characteristics, though this increased over time; and that Whites and Asian Americans were over-represented, while African Americans, Hispanics, and Native Americans were under-represented when compared to the racial composition of the United States. Graham (1992) examined trends over time for the inclusion of African American participants in APA journals and found that the representation of African Americans declined from 1970 to 1989. A more recent study of journals focusing on adolescents, however, found an opposite trend - the majority of articles did not have samples that were a majority White, and over $40 \%$ of the articles included multiple ethnic groups (Levesque 2007).

\section{Research questions}

We were interested in both the breadth and depth of scholarship within LHB. As such, we had the following research questions:

RQ1: Has article organization, including length of manuscripts, length of titles, punctuation in titles, and number of references, changed throughout $L H B^{\prime}$ 's history?

RQ2: How have author affiliations, the country of affiliation, the Carnegie classification of the affiliation, and the author's gender changed throughout LHB's history?

RQ3: What topic areas are represented in $L H B$ ? Has there been diversification in these areas throughout $L H B^{\prime}$ s history?

RQ4: What areas of law and areas of psychology are connected to the research published in $L H B$ ? Has the connection to law or psychology shifted throughout $L H B^{\prime}$ s history?

RQ5: What types of samples have been included in research published in LHB? What are the ethnic, racial, and age compositions of the samples? Has there been diversification in these sample types throughout $L H B^{\prime}$ s history?

RQ6: Are there sample characteristics that are included more often in some areas of research as compared to other areas of research?

RQ7: What impact have LHB articles had on the field through Google Scholar citations and citations within case law? What variables predict these citations?

\section{Method}

\section{Coding scheme}

Two independent coders conducted a preliminary review of all articles published in $L H B$ between 1977 and 2016 and removed introductions to special issues, book reviews, comments, 
replies, announcements, errata, and obituaries. The final sample included original research and review papers published between 1977 (volume 1, issue 1) and 2016 (volume 40, issue 6) $(N=$ 1360). Articles were coded during 2016, and citation metrics were collected in early 2017. For interrater reliability, all articles were coded by one of the authors and a subset of articles were coded by another author (10\%). We assessed interrater reliability using two metrics, percent agreement and Cohen's (1960) kappa. For each variable, percent agreement ranged from 83.2 to $100 \%$ and all variables had a kappa indicating substantial agreement based on Landis and Koch's (1977) criteria. Specific values are included within the description of each variable below.

\section{Coded variables}

Article structure and organization

Information about each article was coded including the journal citation information (volume/issue/page numbers) and the year. Each article was coded for article length (in pages), title length (in words), use of punctuation in the title (colon, question mark, and quotation marks), and the number of references. The number of references was included only for articles using APA citation guidelines and not articles using footnotes because the citation management system (i.e., Scopus) was unable to produce the number of references within footnotes. As such, number of references was missing for 94 articles (7\%).

To examine trends over time, we divided the articles into the following four decades: (1) 1977 to 1986 ( $n=215 ; 15.8 \%$ ); (2) 1987 to 1996 ( $n=329 ; 24.2 \%$ ); (3) 1997 to 2006 ( $n=359 ; 26.4 \%$ ); (4) 2007 to 2016 ( $n=457 ; 33.6 \%$ ). To measure impact of articles, we coded the number of citations according to Google Scholar (recorded during March 2017), which is a free online search engine that records the number of times the article has been cited by other works. Google Scholar has the advantage of including published and unpublished works, as well as openaccess and subscription-access journals (Falagas et al. 2008). We further coded the number of Google Scholar citations to examine the outlets that are citing to $L H B$ articles including the number of court cases (federal and state) and the number of citations from other LHB articles. In addition to Google Scholar citations, we also included the number of citations as recorded in Scopus. In comparing Google Scholar to Scopus, the correlation between the two metrics was highly correlated $(r=.96, p<.001)$. As such, we only included Google Scholar citations as the dependent variable because of its ability to separate case law and research articles, and Google Scholar's inclusion of non-published works.

\section{Authorship}

To measure trends in authorship, first we coded the number of authors in each article. Then, each article was coded for first author's gender. Gender was based on first names when they were clearly gendered, supplemented by personal knowledge of authors and Internet searches. In some instances, no gender could be confirmed and those were coded as unknown $(0.9 \%, n$ $=12$ ). We also recorded first author's listed affiliation. Affiliation was further coded by country (United States, Canada, United Kingdom, Australia/New Zealand, or other) and whether the 
affiliation was a university/academic institution or other type of institution. Similar to the gender coding, this information was gleaned from personal information and supplemented by Internet searches. If the author's affiliation was a US academic institution, we also indicated the institution's Carnegie Classification of Institutions of Higher Education, which is a framework for classifying US academic institutions (Indiana University Center for Postsecondary Research 2015). All institutions that confer a 4-year degree or higher as the main focus are categorized as doctoral program, master's programs, or baccalaureate programs. Doctoral programs are further assigned to one of three categories based on the measured level of research activity (highest, higher, and moderate). For simplicity, Carnegie Classification was coded as either "Doctoral University: Highest Research Activity" or "other classification."

We also coded corresponding author and affiliation, if the corresponding author was different from the first author, and the corresponding author's gender or affiliation differed from the first author. Overall, there were 60 articles (4.4\%) for which gender of corresponding author differed from the first author, and 51 (3.8\%) for which affiliation of corresponding author differed from the first author. All analyses were performed with either the corresponding author or the first author variable; however, results did not differ. As such, only analyses using the first author variable are presented.

Research topic

To gain a better understanding of the trends in research topics published in $L H B$, each article was coded for 31 research topics: (a) risk assessment, (b) competency and criminal responsibility, (c) civil commitment, (d) criminal offending/recidivism, (e) police and investigations, (f) Miranda rights, (g) lie detection/deception, (h) confessions and interrogations, (i) eyewitness/ memory, (j) court and trial procedures, (k) pre-trial publicity (PTP), (l) criminal jury/judicial decision-making, (m) civil jury/judicial decision-making, (n) sentencing and pleas, (o) death penalty, (p) alternatives to court, (q) corrections, (r) psychopathy, (s) sex offenders, (t) mentally ill offenders/psychiatric patients, $(\mathrm{u})$ victims and trauma, $(\mathrm{v})$ child maltreatment, $(\mathrm{w})$ domestic violence, $(x)$ sexual harassment, (y) experts, (z) race/ethnicity and gender, (aa) juvenile justice, (bb) family issues, (cc) procedural justice, (dd) law and policy, and (ee) general psychology and law. See "Appendix" for specific research topics and coding criteria.

To establish categories for research topics, we employed both deductive and inductive procedures (Elo and Kyngäs 2008). Deductive procedures involved deriving research topic categories from the most frequently cited one, two, and three-word combinations in article titles and author keywords (since inception of author keywords in LHB in 2002) using an online text analysis software tool (Textanalyser.net). Inductive procedures involved developing research topic categories from each article's content using an iterative process (see Hsieh and Shannon 2005; Mayring 2000), in which coders began with initial categories developed from a commonly used psychology and law textbook (Green and Heilbrun 2014; Wrightsman's Psychology and the Legal System, 8th edition) and then coders/authors discussed any additional categories based on article content. These two methods complemented each other because while the deductive approach included more specific topics but commonly used phrases (e.g., domestic violence, civil 
commitment, sexual harassment, lie detection/deception, Miranda), the inductive approach included broader research topics not captured with the deductive approach (e.g., court and trial procedures, race/ethnicity and gender, law and policy, family issues, victims/trauma).

For each article, up to two research topics were selected. Percent agreement for research topic between coders was $90.3 \%$ with a Cohen's kappa of .84 , which indicates almost perfect agreement (Landis and Koch 1977). In $22.6 \%$ of the articles $(n=518)$, coders indicated two research topics, with the remaining only having a single coded research topic. For analyses, we included both first and second topics coded, therefore research topics are not mutually exclusive.

Areas of law

To determine each article's specific connection to law, we coded the most applicable area of law: (a) criminal law, (b) juvenile law (i.e., juvenile criminal law issues), (c) evidence (including expert witnesses), (d) family law, (e) Constitutional law (non-criminal), (f) employment law (including sexual harassment in an employment setting), (g) tort law, (h) mental health law (i.e., issues in both criminal and civil law related to mental health), and (i) general law (i.e., applies across multiple areas of law, legal institutions, legal processes, and legal education). There were several areas of law with few occurrences (i.e., contracts, property, international law, elder law, tax law, business or corporate law, health law, alternative dispute resolution, and military law), so these were collapsed into a single "other" category $(n=22)$. Percent agreement for this variable was $86 \%$. Interrater reliability was substantial with a kappa of .76 (Landis and Koch 1977).

Areas of psychology

To examine each article's specific connection to psychology we coded each article for the most applicable area of psychology: (a) social-cognitive psychology (i.e., human behavior in situations, attitudes and behaviors, and cognitive function) (b) clinical psychology (i.e., assessment and treatment of mental health issues), (c) developmental psychology (i.e., issues over the life course), (d) brain or neuro psychology (i.e., brain and physiological functioning), (e) research methods (i.e., specific research methodologies as applied to legal issue), (f) psychology and law (e.g., addressed the state of the field), and (g) none, just legal (e.g., legal processes, legal standards). If necessary, articles were coded for more than one area of psychology. Percent agreement between coders was $83.2 \%$ and interrater reliability was calculated at .72, indicating substantial agreement (Landis and Koch 1977).

Type of sample and sample demographics

Sample type was coded according to 13 groups: (a) college students, (b) adult community members (including mock jurors and law students), (c) youth community members, (d) attorneys, (e) judges, (f) actual jurors, (g) adult or juvenile criminal offenders, (h) criminal justice professionals, (i) military or service persons, (j) experts (i.e., mental health professionals, scholars), (k) non-criminal psychiatric patients, (l) documents (e.g., cases, meta-analyses), or (m) theory/review articles with no sample. Within each article, there may have been multiple samples 
both across studies and within studies. When an article reported more than one type of sample, including pilot data, each sample was coded separately. Percent agreement was $88.6 \%$ with a kappa of .85, indicating almost perfect agreement (Landis and Koch 1977).

The total number of samples across all articles was $N=2,157$. For each sample identified, we recorded the mean age and the percentage of the sample from each race and/or ethnicity (coding for White, Black, Latino/Hispanic, Asian, Middle Eastern, and Native American). If authors did not provide mean age or details about the race and/or ethnicity, the sample was coded as "not providing enough information." If authors reported sample demographics aggregately for each sample (e.g., reported aggregate mean age for community members and college students for the study), then the aggregate values were used for each sample type. Later publications were more likely to report percent race and/or ethnicity, whereas earlier publications were not as descriptive and only reported the percent of White participants (or reported using terms such as "mostly White"). For that reason, we also coded race and/or ethnicity as either: (a) mostly White ( $>50 \%$ of the sample) or (b) mostly non-White ( $<50 \%$ of the sample).

\section{Online sample}

All samples were coded for information about whether the sample was an online sample. An online sample was defined as one in which participants were recruited online and the data were collected exclusively online. This did not include a lab-based study in which the data were collected over a computer (or the lab computer's Internet) or if college students were sent a survey via online methods. If the sample was an online sample, we also coded for the source of the online data (e.g., Mturk, StudyResponse, TESS).

\section{Results}

\section{Citation indices}

During the first decade and a half in print, LHB published four issues per year (for some volumes, this was condensed to two or three issues), with an average of 22 articles per year. In 1990 for volume 14, when Ronald Roesch was in his first year as editor, LHB began publishing six issues per year (February, April, June, August, October, and December), with an average of 38 articles per year. Per Google Scholar citations recorded in March 2017, articles published in $L H B$ ranged from having a total of $0-994$ citations $(M=64.96, S D=86.99)$. Approximately $19 \%(n=255)$ of the articles had 100 or more Google Scholar citations. The most cited article by Hanson and Thornton (2000) had 994 citations at the time of coding and is an article that compared three risk assessment tools for sex offenders. The second most cited article by Wells et al. (1998) had 883 citations at the time of coding and is AP-LS's Scientific Review article on eyewitness identification recommendations for lineups and photospreads. The third most cited article by Bornstein (1999) had 694 citations at the time of coding and is an article about the ecological validity of jury studies. We present the top 20 most cited research articles in Table 1. 
Table 1. The 20 most cited articles from $L H B$ at the time of coding

\begin{tabular}{|c|c|c|c|}
\hline Author(s) (year) & Article title & Research topic(s) & Citations \\
\hline $\begin{array}{l}\text { Hanson and Thornton } \\
\text { (2000) }\end{array}$ & $\begin{array}{l}\text { Improving risk assessments for } \\
\text { sex offenders: a comparison of } \\
\text { three actuarial scales }\end{array}$ & Risk assessment; sex offenders & 994 \\
\hline Wells et al. (1998) & $\begin{array}{l}\text { Eyewitness identification } \\
\text { procedures: Recommendations } \\
\text { for lineups and photospreads }\end{array}$ & Eyewitnesses and memory & 883 \\
\hline Bornstein (1999) & $\begin{array}{l}\text { The ecological validity of jury } \\
\text { simulations: Is the jury still out? }\end{array}$ & Jury or judicial decision making & 694 \\
\hline Rice et al. (1992) & $\begin{array}{l}\text { An evaluation of a maximum } \\
\text { security therapeutic community } \\
\text { for psychopaths and other } \\
\text { mentally disordered offenders }\end{array}$ & $\begin{array}{l}\text { Psychopathy; mentally ill } \\
\text { offenders and psych. patients }\end{array}$ & 627 \\
\hline $\begin{array}{l}\text { Steinberg and } \\
\text { Cauffman (1996) }\end{array}$ & $\begin{array}{l}\text { Maturity of judgment in } \\
\text { adolescence: Psychosocial } \\
\text { factors in adolescent decision } \\
\text { making }\end{array}$ & $\begin{array}{l}\text { Competency and criminal } \\
\text { responsibility; juvenile justice }\end{array}$ & 570 \\
\hline Harris et al. (1991) & $\begin{array}{l}\text { Psychopathy and violent } \\
\text { recidivism }\end{array}$ & $\begin{array}{l}\text { Psychopathy; criminal } \\
\text { offending/recidivism }\end{array}$ & 547 \\
\hline Loftus et al. (1987) & $\begin{array}{l}\text { Some facts about "weapon } \\
\text { focus" }\end{array}$ & Eyewitnesses and memory & 518 \\
\hline $\begin{array}{l}\text { Grisso and Appelbaum } \\
\text { (1995) }\end{array}$ & $\begin{array}{l}\text { The MacArthur Treatment } \\
\text { Competence Study. III-Abilities } \\
\text { of Patients to consent to } \\
\text { psychiatric and medical } \\
\text { treatments }\end{array}$ & $\begin{array}{l}\text { Competency and criminal } \\
\text { responsibility }\end{array}$ & 493 \\
\hline Rice and Harris (1997) & $\begin{array}{l}\text { Cross-validation and extension } \\
\text { of the Violence Risk Appraisal } \\
\text { Guide for child molesters and } \\
\text { rapists }\end{array}$ & Risk assessment; sex offenders & 463 \\
\hline Rice and Harris (2005) & $\begin{array}{l}\text { Comparing effect sizes in } \\
\text { follow-up studies: ROC area, } \\
\text { Cohen's d, and r }\end{array}$ & General psych and law & 458 \\
\hline Grisso et al. (2003) & $\begin{array}{l}\text { Juveniles' competence to stand } \\
\text { trial: A comparison of } \\
\text { adolescents' and adults' } \\
\text { capacities as trial defendants }\end{array}$ & $\begin{array}{l}\text { Juvenile justice; competency } \\
\text { and criminal responsibility }\end{array}$ & 443 \\
\hline $\begin{array}{l}\text { Goodman and Reed } \\
\text { (1986) }\end{array}$ & $\begin{array}{l}\text { Age differences in eyewitness } \\
\text { testimony }\end{array}$ & Eyewitnesses and memory & 437 \\
\hline Slovic et al. (2000) & $\begin{array}{l}\text { Violence risk assessment and } \\
\text { risk communication: The } \\
\text { effects of using actual cases, } \\
\text { providing instruction, and } \\
\text { employing probability versus } \\
\text { frequency formats }\end{array}$ & Risk assessment & 435 \\
\hline Kassin et al. (2010) & $\begin{array}{l}\text { Police-induced confessions: Risk } \\
\text { factors and recommendations }\end{array}$ & Confessions and interrogations & 425 \\
\hline
\end{tabular}




\begin{tabular}{|c|c|c|c|}
\hline Author(s) (year) & Article title & Research topic(s) & Citations \\
\hline $\begin{array}{l}\text { Appelbaum and Grisso } \\
\text { (1995) }\end{array}$ & $\begin{array}{l}\text { The MacArthur Treatment } \\
\text { Competence Study. I-Mental } \\
\text { illness and competence to } \\
\text { consent to treatment }\end{array}$ & $\begin{array}{l}\text { Competency and criminal } \\
\text { responsibility }\end{array}$ & 424 \\
\hline Leistico et al. (2008) & $\begin{array}{l}\text { A large-scale meta-analysis } \\
\text { relating the hare measures of } \\
\text { psychopathy to antisocial } \\
\text { conduct }\end{array}$ & Risk assessment; psychopathy & 424 \\
\hline $\begin{array}{l}\text { Seagrave and Grisso } \\
(2002)\end{array}$ & $\begin{array}{l}\text { Adolescent development and the } \\
\text { measurement of juvenile } \\
\text { psychopathy }\end{array}$ & Psychopathy; juvenile justice & 419 \\
\hline Steblay (1992) & $\begin{array}{l}\text { A meta-analytic review of the } \\
\text { weapon focus effect }\end{array}$ & Eyewitnesses and memory & 406 \\
\hline $\begin{array}{l}\text { Deffenbacher et al. } \\
\text { (2004) }\end{array}$ & $\begin{array}{l}\text { A meta-analytic review of the } \\
\text { effects of high stress on } \\
\text { eyewitness memory }\end{array}$ & Eyewitnesses and memory & 402 \\
\hline $\begin{array}{l}\text { Baker and Emery } \\
\quad \text { (1993) }\end{array}$ & $\begin{array}{l}\text { When every relationship is } \\
\text { above average-Perceptions } \\
\text { and expectations of divorce at } \\
\text { the time of marriage }\end{array}$ & Family issues & 390 \\
\hline
\end{tabular}

We also coded the number of Google Scholar citations stemming from citations by a court case and the number of citations that were from non-LHB outlets. Approximately $10.5 \%(n=143)$ of the articles had at least one citation by a court case. Of those articles with citations in a court case, the mean number of case law citations per article was $3.43(S D=4.22)$, and ranged from 1 to 27 cases that cited to the article. In examining the specific research topics cited by court cases, the majority of the articles cited were for studies that examined issues of criminal jury/judicial decision-making $(n=54)$ and eyewitness/memory $(n=42)$. Of the top six most cited articles in a court case, two were White papers (eyewitness memory, Wells et al. 1998; and policeinduced confessions, Kassin et al. 2010) and three were meta-analyses on eyewitness memory (Deffenbacher et al. 2004 on stress effects on memory; Deffenbacher et al. 2006 on source confusion; and Steblay 1992 on the weapon focus effect).

When examining whether citations emerged from $\angle H B$ or from other outlets, the vast majority of citations were from non- $L H B$ outlets - the average percent of non- $L H B$ citations for each article was $95.1 \%$ - meaning that $L H B$ articles are being cited well beyond other $L H B$ articles. We did not include this citation index in subsequent analysis due to the high frequency with which non- $L H B$ outlets cited $L H B$ articles.

\section{Analytic strategy}

To answer the research questions, a four-step process was employed to examine each citation index. First, to answer RQ1 through RQ6, we examined whether trends shifted over $L H B^{\prime}$ s four decades by comparing frequencies within each decade using Chi square analysis and measuring significant differences between each subsequent decade using the column proportion $\mathrm{z}$ - 
test with Bonferroni adjustments. The remaining three steps were based on procedures described by Haslam et al. (2008). Second, we examined the bivariate relationship of each predictor to two citation metrics: (a) total number of Google Scholar citations and (b) whether the article was cited by a court case (yes or no) using correlations and Chi square analysis, respectively. Third, we regressed the predictors on each citation metric to assess the unique contributions. The Google Scholar citation dependent variable was skewed; therefore, we log transformed it for regression analyses. Within each regression, year of publication centered at 1997 (median year) was included to account for the time needed for articles to garner citations. In each model to follow, publication year as a control variable significantly predicted the dependent variables; however, we do not further discuss publication year because the relationship is consistent across all models. For the fourth step, we estimated a final regression model with each of the significant predictors from the previous models.

\section{Article structure and organizational properties}

Most of the structural and organizational variables increased significantly over time. Title length increased each decade, $F(3,1356)=19.65, p<.001$, from approximately 11 words the first decade $(M=10.74, S D=3.90)$ to approximately 13 words in the most recent decade $(M=12.96$, $S D=3.82$ ). Longer titles may reflect the change in American Psychological Association's (APA) publication recommendations. While the 6th edition of the APA's publication manual (2009) recommends titles not be greater than 12 words, the previous two editions (4th edition, 1994; 5th edition, 2001) both recommended 10-12 words. Similarly, the number of references increased each decade, $F(3,1262)=39.37, p<.001$, from approximately 31 references the first decade $(M=31.06, S D=27.04)$ to 53 references the fourth decade $(M=52.74, S D=22.82)$. The number of authors for each article also increased each decade, $F(3,1356)=88.74, p<.001$, from 1.68 authors the first decade $(S D=0.88)$ to 3.31 authors the fourth decade $(S D=1.54)$. In addition, $L H B$ articles increased in the number of pages from the first decade to the third decade, $F(3,1356)=75.75, p<.001,(M=14.63, S D=9.22$ and $M=17.62, S D=6.77$, respectively $)$; however, the most recent decade included significantly fewer pages than all previous decades $(M=11.31$, $S D=3.76$ ). It should be clarified, however, that there were some printing changes to the journal that likely affected this most recent drop in the last decade. From 1977 to 2007, LHB was printed on 63/4-by-91/2-inch pages, but beginning in 2007, LHB was printed on $81 / 2$-by-11-inch pages. During the first year of publication in the larger paper format (2007), the bottom margin was large and the text space size was equivalent to the text size with the smaller pages. In 2008, during the most recent decade of the analysis, the margin decreased and the text space size increased, thus allowing for more words per page. Further, in 2012, when LHB changed publishers, the font size decreased, again permitting more words per page. Thus, mean values for number of pages from the last decade are not comparable to the previous three decades.

With respect to punctuation in titles, both the use of colons, $\chi^{2}(3)=264.01, p<.001$ and question marks, $\chi^{2}(3)=17.98, p<.001$ have increased, while the use of quotation marks have remained consistent, $\chi^{2}(3)=3.33, p=.34$. Specifically, while only $18(8.4 \%)$ article titles used a colon between 1977 and 1986, and 38 (11.6\%) between 1987 and 1996, the number of titles with colons significantly jumped to 196 (54.6\%) between 1997 and 2006, and 240 (52.5\%) between 
2007 and 2016. A similar trend emerged with the question mark, albeit not as drastically. While only $13(6.0 \%)$ article titles used a question mark between 1977 and 1986, and 16 (4.9\%) between 1987 and 1996, the number of titles with question marks jumped to 40 (11.1\%) between 1997 and 2006, and 58 (12.7\%) between 2007 and 2016. Using Chi square, there were not any significant relationships between the structural and organizational variables and whether the article was cited by a court.

Next, we examined whether structural and organizational properties were related to Google Scholar citations and citations by the court (Table 2). Article length and title length both had a significant bivariate relationship with Google Scholar citations; articles with more pages but titles with fewer words resulted in more Google Scholar citations. Next, a regression equation was estimated with the structural and organizational property variables, $F(7,1230)=40.17, p<$ $0.001, R^{2}=0.19$. Similar to the bivariate analysis, article length and title length significantly predicted Google Scholar citations in the same direction as the bivariate analyses. The presence of a colon became a significant predictor in the model; the presence of a colon significantly increased the number of Google Scholar citations.

Table 2. Correlations and regression weights for relationships between publication information and citations

\begin{tabular}{|c|c|c|c|c|}
\hline \multirow[b]{2}{*}{ Predictor } & \multicolumn{2}{|c|}{ Google Scholar citations } & \multicolumn{2}{|c|}{ Case law citations } \\
\hline & $r$ & $\beta$ & $\chi^{2}$ & $\operatorname{Exp}(\beta)$ \\
\hline Article length (pages) & $0.31^{* * *}$ & $0.28^{* * *}$ & - & $1.04^{* *}$ \\
\hline Title length (words) & $-0.08^{* *}$ & $-0.06^{*}$ & - & 0.97 \\
\hline Colon in title & -0.04 & $0.09^{* *}$ & 0.05 & $2.13^{* * *}$ \\
\hline Quotation in title & -0.01 & -0.02 & 1.01 & 1.57 \\
\hline Question mark in title & -0.03 & 0.02 & 1.04 & 0.91 \\
\hline Number of references & 0.04 & 0.01 & - & 1.00 \\
\hline Year & $-0.29^{* * *}$ & $-0.29^{* * *}$ & - & $0.94^{* * *}$ \\
\hline
\end{tabular}

Next, a logistic regression was estimated to predict whether structural and organizational property variables predicted whether an article was cited by a court case. A test of the full model against a constant-only model was statistically significant, $\chi^{2}(7)=61.35, p<.001, R^{2}=.05$ and correctly classified $88.9 \%$ of cases. Article length and the presence of a colon in the title significantly predicted citation by the courts, such that longer articles and articles with a colon were more likely to be cited by a court case.

\section{Author and affiliation information}

Across $L H B^{\prime}$ s history, male first authors were more common in the earlier years, but proportions have shifted and female first authors are now higher relative to male first authors, $\chi^{2}(3)$ $=100.85, p<.001$. Specifically, during the journal's first decade, first authorships were significantly more male dominated (14.6\% female), but in the most recent decade, first authorships were more female dominated (53.6\% female; see Fig. 1$)$. Similarly, author affiliation has become 
more diverse as more non-US-based researchers publish in LHB. Although US first authors were significantly more common across all decades than non-US first authors, the number of nonUS first authors has increased, $\chi^{2}(12)=69.49, p<.001$. During the journal's first decade, $86 \%$ of first authors were from the US, 7\% were Canadian, $6.1 \%$ were from the UK, and less than $0.5 \%$ were Australian and from all other countries. Contrast that with the most recent decade in which $67.8 \%$ of first authors were from the US, $13.8 \%$ were Canadian, $5.7 \%$ were from the UK, $4.4 \%$ were Australian, and $8.3 \%$ were from all other countries. There were no trends across each decade for either first author type of institution, $\chi^{2}(3)=5.10, p=.17$, or first author institution's Carnegie classification, $\chi^{2}(3)=7.27, p=.06$.

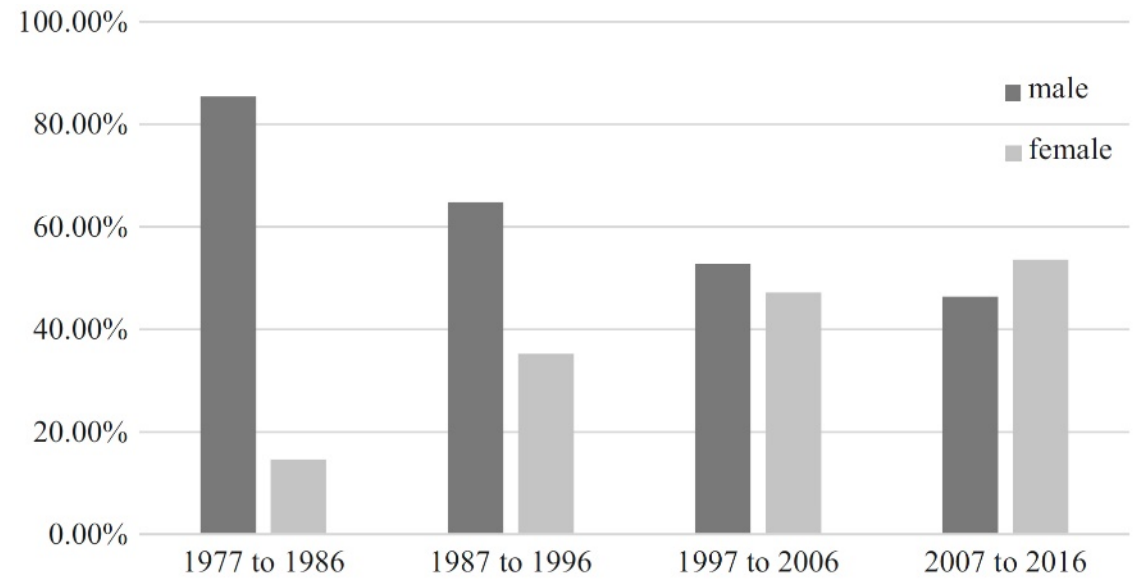

Figure 1. Proportion of first author gender over time

Next, we examined whether author and affiliation information (country of affiliation was collapsed into two groups: US and all other countries) were related to Google Scholar citations and citations by the court. First author gender was the only variable that had a significant bivariate relationship with Google Scholar citations such that male first authors had articles with significantly more citations than female first authors. Chi square analyses revealed a significant bivariate relationship for both first-author gender and country of affiliation, and whether a court case cited the article. Male first authored articles were significantly more likely to be cited by case law than female first authored articles $(69.7 \%$ of articles cited by the courts had a male first author). US first authored articles were more likely to have case law citations than non-US first authored articles ( $86.7 \%$ of articles cited by the courts had a US first author).

A regression equation was estimated with author characteristics (Table 3). In the model, Carnegie classification was not included because it overlapped with both first author country and the first author affiliation type, as Carnegie classifications are given only to US academic institutions. An interaction term between gender and year was added because once year and gender were added to the model, gender was no longer significant, suggesting a significant gender $\times$ year interaction. The regression with the interaction term yielded a significant model, $F(6,1309)=34.18, p<.001, R^{2}=0.14$. The number of authors significantly predicted Google 
Scholar citations, with more authors resulting in more Google Scholar citations. There was a significant interaction effect for year $\times$ gender on Google Scholar citations, demonstrating that articles authored by males in the earlier years contributed to more Google Scholar citations. The main effect of gender was also significant, suggesting that once controlling for the main effect of year and the gender $\times$ year interaction, women first-authored articles contributed to more Google Scholar citations.

Table 3. Correlations and regression weights for relationships between author characteristics and citations

\begin{tabular}{|c|c|c|c|c|}
\hline \multirow[b]{2}{*}{ Predictor } & \multicolumn{2}{|c|}{ Google Scholar citations } & \multicolumn{2}{|c|}{ Case law citations } \\
\hline & $r$ & $\beta$ & $\chi^{2}$ & $\operatorname{Exp}(\beta)$ \\
\hline Number of authors & -0.02 & $0.12^{* * *}$ & - & 1.03 \\
\hline First author gender & $-0.09^{* *}$ & $0.08^{* *}$ & $7.98^{* *}$ & 0.76 \\
\hline First author country & 0.02 & 0.02 & $8.47^{*}$ & 0.64 \\
\hline $\begin{array}{l}\text { First author type of in- } \\
\text { stitution }\end{array}$ & 0.05 & 0.02 & 0.01 & 0.84 \\
\hline $\begin{array}{l}\text { First author institution } \\
\text { carnegie }\end{array}$ & -0.03 & - & 1.03 & - \\
\hline Year & $-0.29^{* * *}$ & -0.19 & - & $0.98^{*}$ \\
\hline Year $\times$ gender & - & $-0.28^{* * *}$ & - & $0.15^{* * *}$ \\
\hline
\end{tabular}

A logistic regression was estimated to predict whether author characteristics predicted whether an article was cited by a court case (Table 3). Similar to the regression for Google Scholar citations, an interaction term between gender and year was included. An interaction term between country of affiliation and year was also included, however, this interaction term was nonsignificant and was not included in the final model. A test of the full model against a constant-only model was statistically significant, $\chi^{2}(4)=62.44, p<.001, R^{2}=.05$ and correctly classified $89.5 \%$ of cases. The only significant predictor was the year $\times$ gender interaction term; however, there were no longer main effects for gender or country of affiliation. This demonstrates that male first-authored articles with earlier publications had more citations from the courts, but that there is not an overall main effect of gender once controlling for year and the gender $\times$ year interaction. With respect to country of origin, the first author's country of origin does not uniquely contribute to citations by the court when controlling for year, perhaps because there were a greater number of US first authors in earlier $L H B$ articles.

\section{Research topics}

Table 4 displays the number of articles within each of the specific research topics and the average number of Google Scholar citations for each research topic. The three most frequent topics collectively accounted for $27.8 \%$ of the research topics including: criminal jury/judicial decision-making $(12.1 \%)$, eyewitnesses/memory $(8.7 \%)$, and competency/criminal responsibility 
(7.0\%). Less frequently studied research topics included: sex offenders $(1.3 \%)$, domestic violence $(1.3 \%)$, civil jury/judicial decision-making, and procedural justice (1.2\%). To present research topic trends through $L H B^{\prime}$ s history, we separated the 31 research topics into five figures to illustrate trends over LHB's history (see Fig. 2a, e). Because the number of research articles varied by decade, research topics are presented as the proportion within each decade, so comparisons can be made across figures and decades.

Table 4. Frequency and Google Scholar citations within each of the specified research topics

\begin{tabular}{|c|c|c|c|c|c|c|c|}
\hline \multirow[b]{2}{*}{ General research topic } & \multirow[b]{2}{*}{ Freq. } & \multirow[b]{2}{*}{$M$} & \multirow[b]{2}{*}{$S D$} & \multicolumn{2}{|c|}{$\begin{array}{l}\text { Google Scholar } \\
\text { citations }\end{array}$} & \multicolumn{2}{|c|}{ Case law citations } \\
\hline & & & & $r$ & $\beta$ & $\chi^{2}$ & $\operatorname{Exp}(\beta)$ \\
\hline $\begin{array}{l}\text { Criminal jury/judicial decision } \\
\text { making }\end{array}$ & 291 & 74.91 & 77.28 & $.13^{* * *}$ & $.14^{* * *}$ & $26.64^{* * *}$ & $1.99^{*}$ \\
\hline Eyewitnesses/memory & 208 & 82.92 & 105.03 & $.09^{* *}$ & $.19^{* * *}$ & $32.69^{* * *}$ & $2.92^{* *}$ \\
\hline Competency/criminal resp. & 168 & 73.52 & 107.05 & .04 & $.08^{*}$ & 1.98 & 0.49 \\
\hline $\begin{array}{l}\text { Mentally ill offenders/psych. } \\
\text { patients }\end{array}$ & 106 & 55.87 & 74.81 & -.02 & $.08^{*}$ & $7.22^{* *}$ & 0.52 \\
\hline General psych and law & 96 & 51.40 & 75.74 & -.01 & -.01 & 2.13 & 0.26 \\
\hline Offending/recidivism & 96 & 70.79 & 101.45 & -.01 & $-.07^{*}$ & 2.13 & 0.80 \\
\hline Death penalty & 94 & 70.85 & 66.56 & .05 & .04 & $39.94^{* * *}$ & $3.41^{* *}$ \\
\hline Experts & 93 & 46.77 & 42.37 & -.03 & -.06 & 1.75 & $0.39^{*}$ \\
\hline Lie detection/deception & 92 & 96.00 & 93.32 & $.07^{* *}$ & $.14^{* * *}$ & 0.32 & 1.79 \\
\hline Risk assessment & 88 & 96.13 & 144.06 & $.06^{*}$ & $.15^{* * *}$ & 3.56 & 0.76 \\
\hline Confessions/interrogations & 88 & 70.05 & 101.48 & $-.07^{*}$ & .03 & 2.84 & $4.07^{* *}$ \\
\hline Juvenile justice & 87 & 54.40 & 94.85 & $-.09^{*}$ & .01 & $8.66^{* *}$ & 0.15 \\
\hline Race/ethnicity or gender issues & 72 & 44.94 & 56.25 & $-.11^{* * *}$ & -.04 & 3.26 & 0.49 \\
\hline Child maltreatment & 70 & 51.26 & 32.67 & .02 & .03 & 2.24 & 0.34 \\
\hline Psychopathy & 67 & 89.48 & 130.22 & .02 & $.09^{* *}$ & $8.28^{* *}$ & 0.53 \\
\hline Law and policy & 63 & 40.38 & 49.85 & $-.07^{*}$ & $-.07^{*}$ & 2.32 & 0.38 \\
\hline Police and investigations & 62 & 35.11 & 41.59 & $-.10^{* * *}$ & -.05 & 0.99 & 0.42 \\
\hline Victims and trauma & 59 & 59.31 & 46.17 & .05 & .06 & 0.91 & 0.63 \\
\hline Court and trial procedures & 52 & 52.35 & 42.69 & .01 & .01 & 1.31 & 1.35 \\
\hline Family issues & 50 & 51.40 & 75.74 & -.02 & -.01 & 2.99 & 0.00 \\
\hline Alternatives to court & 42 & 51.52 & 62.25 & -.04 & .02 & 2.51 & 0.00 \\
\hline Sentencing and pleas & 41 & 38.54 & 50.55 & $-.06^{*}$ & -.04 & 2.93 & 0.17 \\
\hline Corrections & 40 & 39.23 & 46.84 & $-.06^{*}$ & -.03 & $4.84^{*}$ & 0.00 \\
\hline Sexual harassment & 40 & 48.15 & 48.42 & -.01 & .03 & 2.39 & 0.00 \\
\hline Civil commitment & 40 & 38.00 & 29.92 & -.03 & -.03 & 0.01 & 0.66 \\
\hline Pretrial publicity (PTP) & 38 & 62.21 & 48.01 & .02 & .02 & 2.26 & 0.00 \\
\hline Miranda rights & 34 & 58.59 & 67.21 & -.01 & $.08^{* *}$ & 0.93 & $7.92^{*}$ \\
\hline Sex offenders & 32 & 93.72 & 193.26 & -.02 & .03 & 0.05 & 2.80 \\
\hline Domestic violence & 30 & 60.53 & 31.31 & .05 & .04 & 0.13 & 1.73 \\
\hline
\end{tabular}


WyLie ET AL., SCIENTOMETRICS 115 (2018)

\begin{tabular}{lccccccc}
\hline Table 4. Continued & & & & & & \\
\hline $\begin{array}{l}\text { Civil jury/judicial decision } \\
\text { making }\end{array}$ & 29 & 78.14 & 56.79 & .05 & .04 & 0.41 & 0.38 \\
$\begin{array}{l}\text { Procedural justice } \\
\text { Year }\end{array}$ & 28 & 46.71 & 58.32 & -.01 & .04 & 1.66 & 0.00 \\
\hline
\end{tabular}

${ }^{* * *} p<.001,{ }^{* *} p<.01,{ }^{*} p<.05$ 

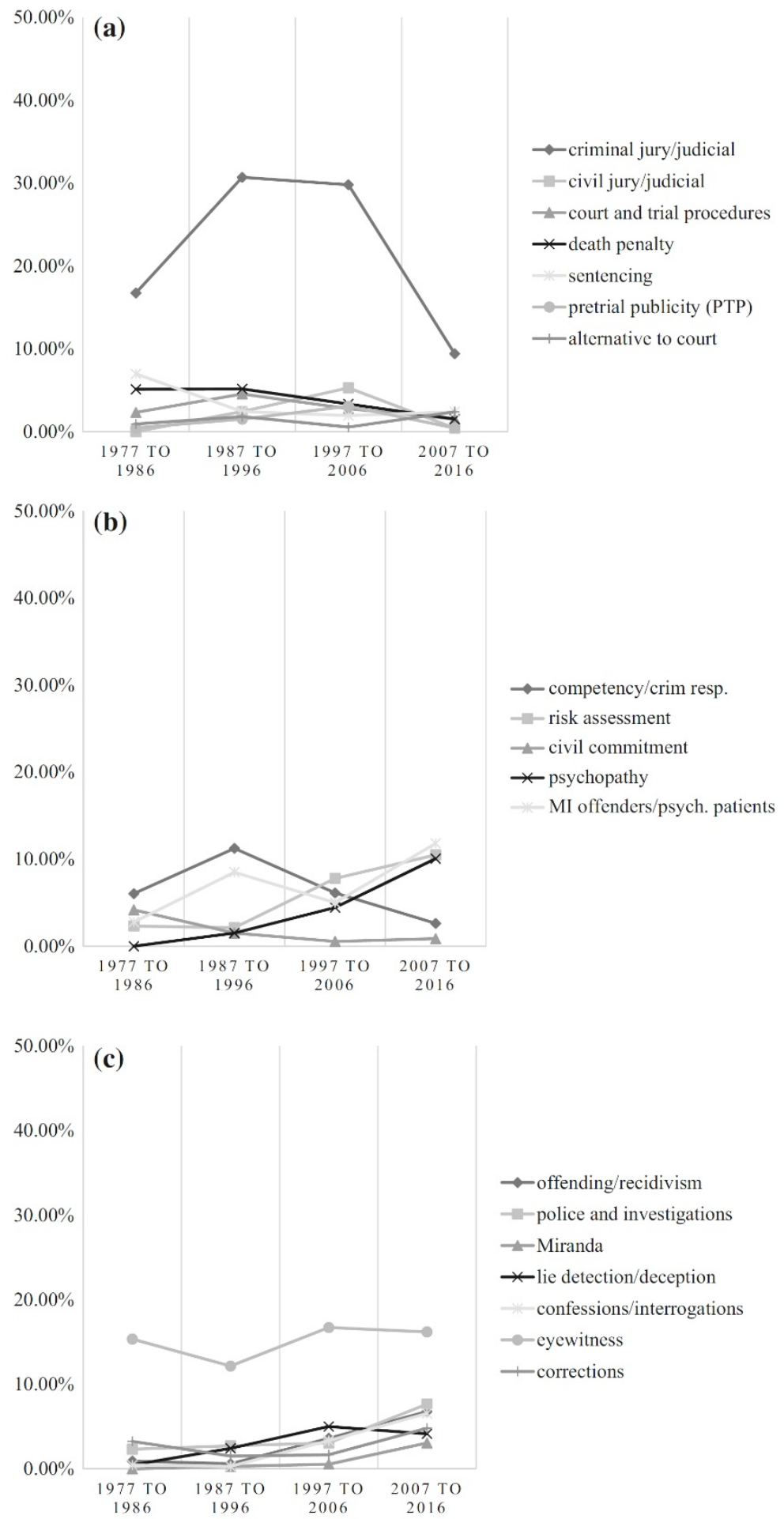

Figure 2. Continues next page 

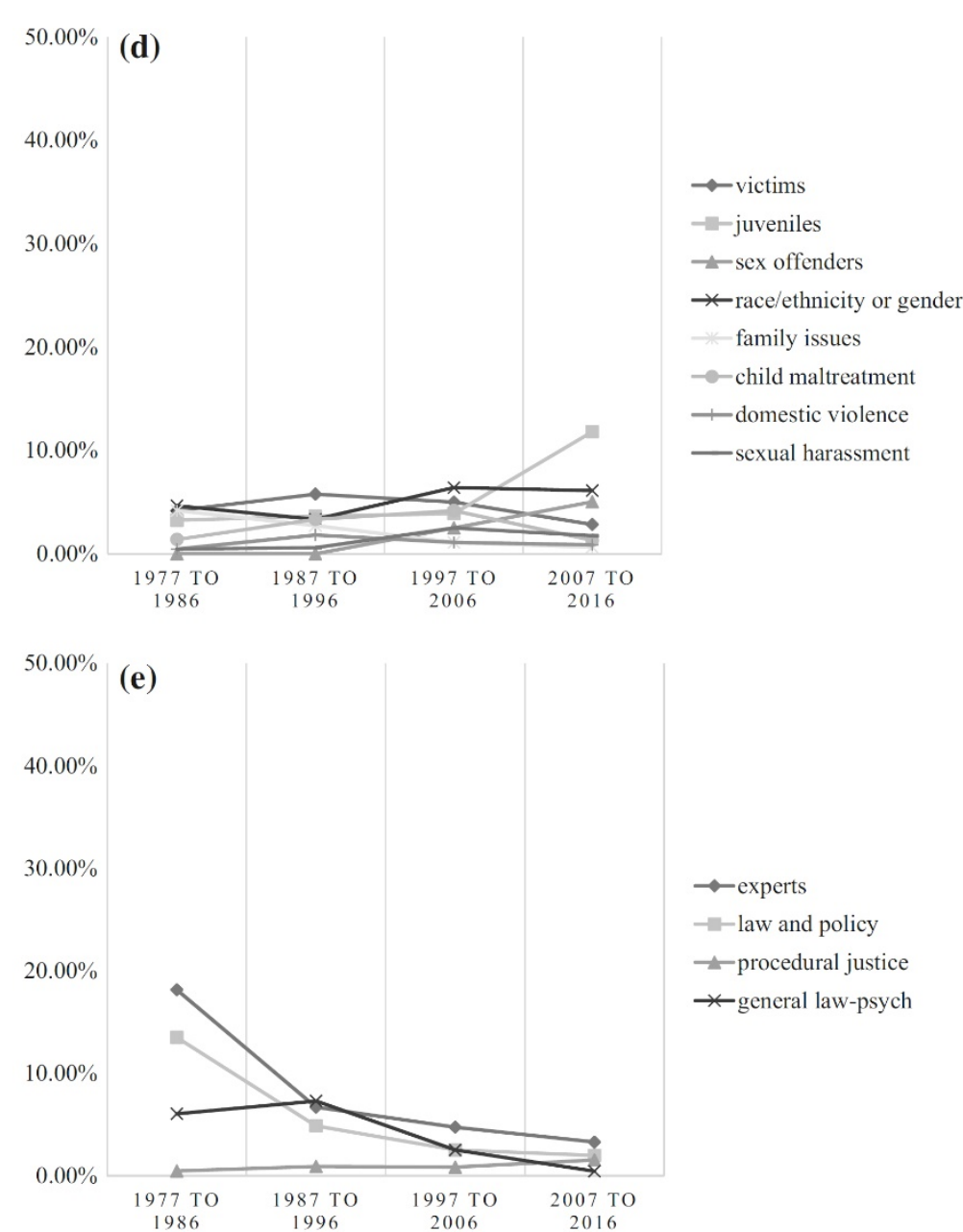

$$
\begin{aligned}
& - \text { experts } \\
& - \text {-law and policy } \\
& \leftarrow \text {-procedural justice } \\
& * \text { general law-psych }
\end{aligned}
$$

Figure 2. (a) Proportion of articles for court and legal procedures research topics over time. (b) Proportion of articles for clinical area research topics over time. (c) Proportion of articles for crime and investigations research topics over time. (d) Proportion of articles for population and crime-specific research topics over time. (e) Proportion of articles for general research topics over time.

Figure 2a displays the research topics related to court and legal procedures. Overall, criminal jury/judicial decision-making remained the greatest proportion of research topics. These trends demonstrated that criminal jury/judicial decision-making increased from the first to the second decade, remained stable through the third decade, and significantly dropped in the most recent decade, $\chi^{2}(3)=74.51, p<.001$. In comparison, while not nearly as frequent as criminal jury/judicial decision-making, civil jury/judicial decision-making was nonexistent in the first decade, reached its peak in the third decade, then significantly declined in the most recent decade, $\chi^{2}(3)=28.29, p<.001$. Although sentencing and death penalty research were the second 
and third most prevalent topics in the first decade, they have each declined through $L H B^{\prime}$ s history. Specifically, sentencing research was highest in the first decade but declined across the remaining three decades, $\chi^{2}(3)=13.90, p=.003$ (the increase in the last decade was not statistically significant); and death penalty research was highest in the first three decades but declined in the last decade, $\chi^{2}(3)=9.75, p=.02$. Conversely, PTP research peaked in the third decade but declined in the fourth most recent decade, $\chi^{2}(3)=11.69, p=.009$. As research into problem solving courts, mediation, and alternative dispute resolution have become more prevalent, alternative-to-court research has increased significantly in the most recent decade, $\chi^{2}(3)=9.03, p$ $<.05$. Lastly, the court and trial procedures research topic remained stable through $L H B^{\prime}$ s history, $\chi^{2}(3)=6.78, p=.08$.

Figure $2 \mathrm{~b}$ displays the research topics related to clinical work. Overall, while some topics have declined, other topics have become more prevalent. For instance, competency/ criminal responsibility and civil commitment were among the most frequent clinical research topics during the first decade; however, civil commitment declined after the first decade, $\chi^{2}(3)$ $=14.13, p=.003$, and competency/criminal responsibility peaked in the second decade but declined each decade thereafter, $\chi^{2}(3)=25.54, p<.001$. Similarly, research on mental illness in offenders/psychiatric patients similarly increased from the first to second decade, declined in the third decade, but again peaked in the most recent decade, $\chi^{2}(3)=21.87, p<.001$. In 1992, there was a special issue on justice and mental health systems, which likely contributed to the peak in the second decade for these topics. The two other clinical research topics, risk assessment, $\chi^{2}(3)=29.69, p<.001$, and psychopathy both significantly increased in the third decade, $\chi^{2}(3)=$ $45.23, p<.001$. Psychopathy - a research area largely unknown in $L H B^{\prime}$ s early life (i.e., no articles prior to 1991) has continued to significantly increase each decade.

Figure 2c displays the research topics related to crime and investigations. With the exception of eyewitness research, which remained fairly stable at relatively high proportions across all time periods, $\chi^{2}(3)=3.35, p=0.34$, most of the other crime and investigation topics have increased since $L H B^{\prime}$ s early years. Research on police and investigations, $\chi^{2}(3)=17.38, p<.001$, and Miranda rights, $\chi^{2}(3)=18.68, p<.001$, remained stable from decades one through three, and then significantly increased in the recent decade. While lie detection/deception research was rather low in the first decade (only a single article), it increased in the third decade (and was higher than all other topics in this area, except for eyewitness research) and remained at a similar proportion in the fourth decade, $\chi^{2}(3)=17.38, p<.001$. Similar to lie detection/deception, there was only a single article within each of the first two decades for confessions and interrogations research; however, this significantly increased into the third and again in the fourth decade, $\chi^{2}(3)=30.50, p<.001$. Criminal offending/recidivism research increased in the third and fourth decades, $\chi^{2}(3)=26.73, p<.001$, and corrections research, while higher in the first decade, experienced a dip during the two middle decades, and again increased to a similar proportion in the fourth decade to the first decade, $\chi^{2}(3)=10.05, p<.05$.

Figure $2 \mathrm{~d}$ displays the research topics related to population and crime-specific research. In general, several of the population and crime-specific research topics have remained relatively stable, including victims, $\chi^{2}(3)=4.50, p=.21$, sexual harassment, $\chi^{2}(3)=6.10, p=.11$, domestic violence, $\chi^{2}(3)=2.59, p=.46$, and race/gender-related topics, $\chi^{2}(3)=4.19, p=.24$. On the other 
hand, some have varied. For instance, child maltreatment research was more common in the second and third decades, than in the first and fourth decades, $\chi^{2}(3)=8.56, p<.05$. Sex offender research emerged for the first time in the third decade and remained consistent into the fourth decade, $\chi^{2}(3)=27.43, p<.001$. One of the greatest increases was for juvenile justice research, which was fairly consistent in the first through third decade, and then increased to the most prevalent population or crime-specific research topic in the fourth decade, $\chi^{2}(3)=33.85, p<$ .001 .

Figure 2e displays the research topics related to general psychology and law issues. With the exception of procedural justice research, $\chi^{2}(3)=1.98, p=.58$, which has remained stable and a relatively low prevalence, the remaining research topics have become less popular over $L H B^{\prime} \mathrm{s}$ history, including experts, $\chi^{2}(3)=54.68, p<.001$, law and policy, $\chi^{2}(3)=49.22, p<.001$, and general law and psychology topics, $\chi^{2}(3)=31.63, p<.001$.

Next, we examined whether research topic was related to number of Google Scholar citations and whether the article was cited by the courts (Table 3). Four research topics had positive bivariate relationships with Google Scholar citations, suggesting that the presence of that research area was related to higher Google Scholar citations: criminal jury/judicial decision-making, eyewitness/memory, lie detection/deception, and risk assessment. Other research topics indicated that the absence of the research area was related to higher Google Scholar citations, including race/ethnicity or gender issues, law and policy, police and investigations, confessions/interrogations, juvenile justice, sentencing and pleas, and corrections. Chi square analyses revealed a significant bivariate relationship for several research topics and whether the article was cited by a court case. Research topics more likely to be cited by the court were criminal jury/judicial decision-making, eyewitness/memory, and death penalty; others less likely to be cited by the court were juvenile justice, psychopathy, and corrections.

The regression model with each of the research topics dummy coded was significant, $F(32$, $1296)=9.18, p<.001, R^{2}=0.19$. Once in the multivariate regression, most of the research topics with negative correlations were no longer significant, except for law and policy topics. Conversely, some research topics that did not have a significant bivariate correlation did predict Google Scholar citations once controlling for all other research areas and year, including competency/criminal responsibility, mentally ill offenders/psychiatric patients, offending/recidivism, psychopathy, and Miranda rights. In examining the standardized beta weights, the research that was most predictive of Google Scholar citations was eyewitness/memory, followed by risk assessment, jury/judicial decision-making, and lie detection/deception.

The logistic regression with each of the research topics dummy coded predicting citation by the court was significant, $\chi^{2}(32)=185.75, p<.001, R^{2}=.13$, and correctly classified $89.7 \%$ of cases. While controlling for all research topics and publication year, with the exception of research on experts, the remaining research topics significantly increased the likelihood of being cited by the court including, criminal jury/judicial decision-making, eyewitness/memory, death penalty, confessions/interrogations, and Miranda. 
Research topics and author characteristics

We also examined whether there were any notable differences in research topic by first author gender. The research topics that were more male-dominated were: Miranda $\left(82.4 \%\right.$ male), $\chi^{2}(1)$ $=3.00, p<.01$, general psychology and law $(85.1 \%$ male $), \chi^{2}(1)=14.07, p<.001$, risk assessment (71.6\% male), $\chi^{2}(1)=6.51, p<.01$, law and policy $\left(77.4 \%\right.$ male), $\chi^{2}(1)=9.45, p<.01$, and experts $\left(70.3 \%\right.$ male), $\chi^{2}(1)=5.50, p<.05$. The research areas that were more female-dominated were: domestic violence ( $73.3 \%$ female), $\chi^{2}(1)=6.39, p<.05$, alternatives to court ( $66.7 \%$ female), $\chi^{2}(1)$ $=5.63, p<.05$, sexual harassment $(65.0 \%$ female $), \chi^{2}(1)=4.68, p<.05$, victims and trauma $(57.6 \%$ female), $\chi^{2}(1)=6.73, p<.001$, confessions (58.1\% female), $\chi^{2}(1)=5.15, p<.05$, race/ethnicity or gender issues (53.5\% female), $\chi^{2}(1)=4.57, p<.05$, and juvenile justice $(54.0 \%$ female $), \chi^{2}(1)=$ $6.14, p<.05$.

\section{Research area}

To analyze research area, we examined both the substantive area of law and the specific area of psychology. With respect to area of law, two areas comprised approximately three-fourths of the articles, including nonjuvenile criminal law and mental health law. Within areas more commonly associated with civil law issues, the two most common were employment law and torts. Figure 3 displays the number articles within each area of law through $L H B^{\prime}$ s history. Overall, criminal law has remained the most common area of law in $L H B$ articles, which dipped in prevalence in the second decade but then continued to increase, and has consistently composed more than half of the articles, $\chi^{2}(3)=8.82, p<.05$. Two areas have increased through $L H B^{\prime}$ s history, mental health law, $\chi^{2}(3)=13.15, p<.01$, and juvenile law, $\chi^{2}(3)=25.61, p<.001$. Tort law increased during the second and third decades, but has since declined in the most recent decade, $\chi^{2}(3)=15.11, p<.01$. The remaining areas of law have all declined through $L H B^{\prime}$ s history. Family law saw a slight decline beginning in the third decade to the present, $\chi^{2}(3)=8.97$, $p<.05$. Employment law, $\chi^{2}(3)=22.77, p<.001$, evidence law, $\chi^{2}(3)=11.15, p<.05$, and general law, $\chi^{2}(3)=39.92, p<.001$, which were all more popular in the first decade, began to decline in the second decade and each subsequent decade. Two areas of law, constitutional law, $\chi^{2}(3)=$ $4.46, p=.22$, and the areas of law coded as other, $\chi^{2}(3)=1.60, p=.66$, did not significantly shift over time.

With respect to area of psychology, approximately two-thirds of the articles were connected to social-cognitive psychology and another one-fourth of the articles were linked to clinical psychology. Fewer articles were linked to developmental psychology or brain/ neuro psychology. A small proportion of the articles were not linked directly to any area of psychology but instead focused solely on the law or research methods. Furthermore, $6.3 \%$ of the articles were categorized as linking generally to psychology and law, which were often general review/theory articles. Figure 4 displays the number of articles coded by each area of psychology through $L H B^{\prime}$ s history. Overwhelmingly, the largest proportion of research articles over time has consistently been social-cognitive psychology, $\chi^{2}(3)=5.20, p=.16$. Clinical psychology, on the other hand, increased from the first decade and nearly tripled by the last decade, $\chi^{2}(3)=66.08, p<.001$; while law only, and psychology and law articles have had a significant decline each year, $\chi^{2}(3)=55.12, p<.001$ and $\chi^{2}(3)=55.49, p<.001$, respectively. Research 
methods articles increased during the second and third decades but have since declined in the last decade, $\chi^{2}(3)=9.30, p<.05$. There were no significant trends for developmental, $\chi^{2}(3)=7.09$, $p=.06$, or brain/neuro psychology, $\chi^{2}(3)=0.31, p=.96$.

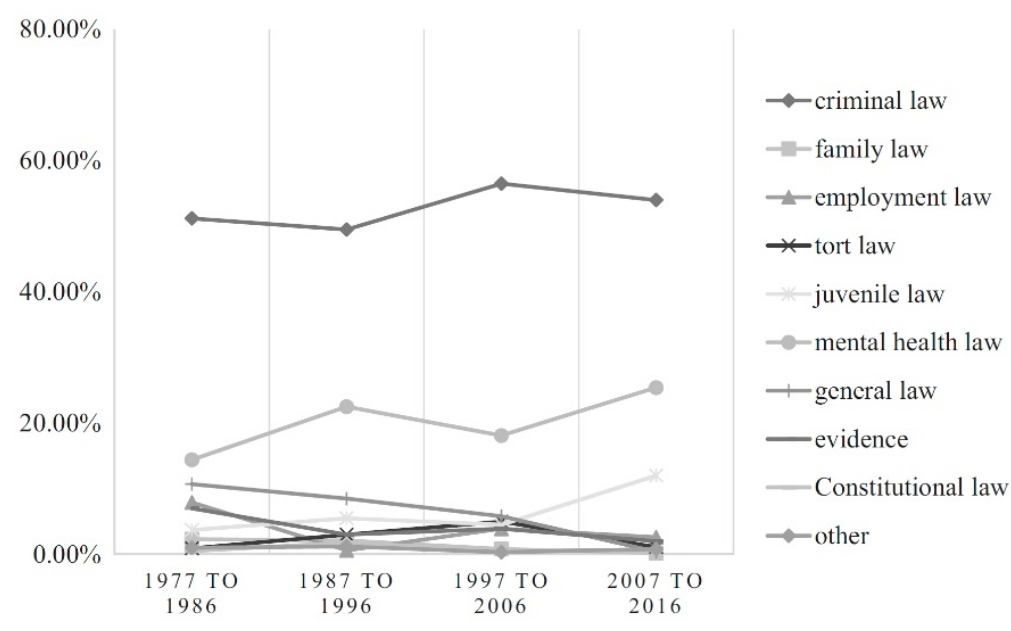

Figure 3. Area of law over time.

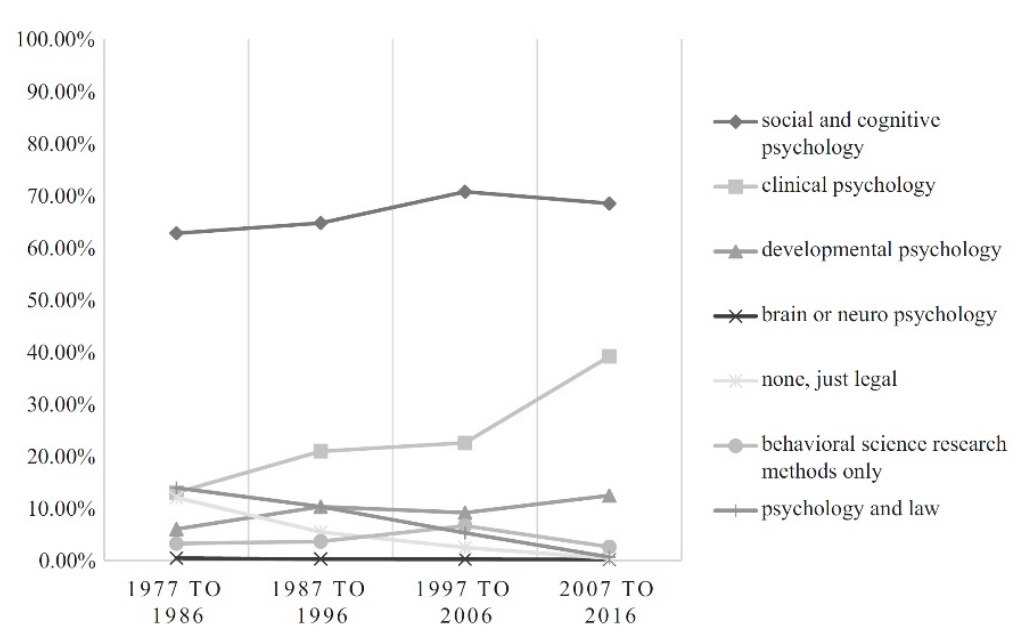

Figure 4. Area of psychology over time

Correlations and regression weights between Google Scholar citations and each specific area of psychology and substantive area of law are presented in Table 5. For analysis, area of law was reduced to four groups: criminal law (criminal law and juvenile law), mental health law, civil law (employment law, tort law, elder law, health law, constitutional law, property law, contracts law, family law), and general law (general law and legal education). The only area of psychology or area of law that had a significant bivariate relationship was research methods, 
demonstrating that the presence of research methods was related to a greater number of Google Scholar citations. Chi square analyses revealed a significant bivariate relationship for whether the article was cited by a court case and criminal law, mental health law, clinical psychology, and developmental psychology.

Table 5. Correlations and regression weights for relationships between research area (psychology and law areas) and citations

\begin{tabular}{|c|c|c|c|c|}
\hline \multirow[b]{2}{*}{ Predictor } & \multicolumn{2}{|c|}{ Google Scholar citations } & \multicolumn{2}{|c|}{ Case law citations } \\
\hline & $r$ & $\beta$ & $\chi^{2}$ & $\operatorname{Exp}(\beta)$ \\
\hline Criminal law & .02 & .12 & $26.03^{* * *}$ & 4.36 \\
\hline Mental health law & .01 & .11 & $13.72^{* * *}$ & 2.14 \\
\hline Civil law & -.02 & .03 & $6.91^{* *}$ & 0.85 \\
\hline General law & .01 & -.01 & 0.60 & 1.18 \\
\hline Social cognitive & .02 & .01 & 3.40 & 0.67 \\
\hline Clinical & -.02 & .02 & $22.36^{* * *}$ & $0.34^{*}$ \\
\hline Developmental & -.01 & .01 & $4.73^{*}$ & $0.33^{* *}$ \\
\hline Brain/neuro & -.01 & -.01 & 0.47 & 0.00 \\
\hline Law only & -.03 & $-.09^{* *}$ & 0.01 & 0.41 \\
\hline Research methods & $.10^{* *}$ & $.09^{* *}$ & 2.08 & 1.31 \\
\hline Psychology-law & -.05 & $-.08^{*}$ & 1.15 & 0.69 \\
\hline Year & - & $-.34^{* *}$ & - & 0.95 \\
\hline
\end{tabular}

${ }^{* * *} p<.001,{ }^{* *} p<.01,{ }^{*} p<.05$

Next, a regression equation was estimated with each area of law and area of psychology dummy coded $(1=$ research area present in the article), which yielded a significant model, $F(12,1316)=14.14, p<0.001, R^{2}=0.11$. Law only and psychology-law areas of law resulted in fewer Google Scholar citations, and research methods articles were still positively related to Google Scholar citations. A logistic regression was estimated to predict whether research area contributed to citations by the court, which was statistically significant, $\chi^{2}(12)=90.15, p<.001$, $R^{2}=.06$ and correctly classified $89.7 \%$ of cases. While controlling for all research areas and publication year, clinical psychology and developmental psychology were the only research areas that significantly predicted the likelihood that the court would cite to the article.

\section{Research approach}

\section{Sample types}

Approximately one-fourth of the articles were theory/review articles without a sample (11.3\%, $n=243)$ or utilized documents/case files as the sample $(13.8 \%, n=298)$, which were not included in the analysis of samples. The total number of samples across all $L H B$ articles was $N=2157$. The number of samples in a single article ranged from one to 15 - with $43.7 \%$ reporting a single sample $(n=594)$, and only a single study reported more than 12 samples $(M=1.71, S D=1.30)$. Figure 5 illustrates the types of samples. 


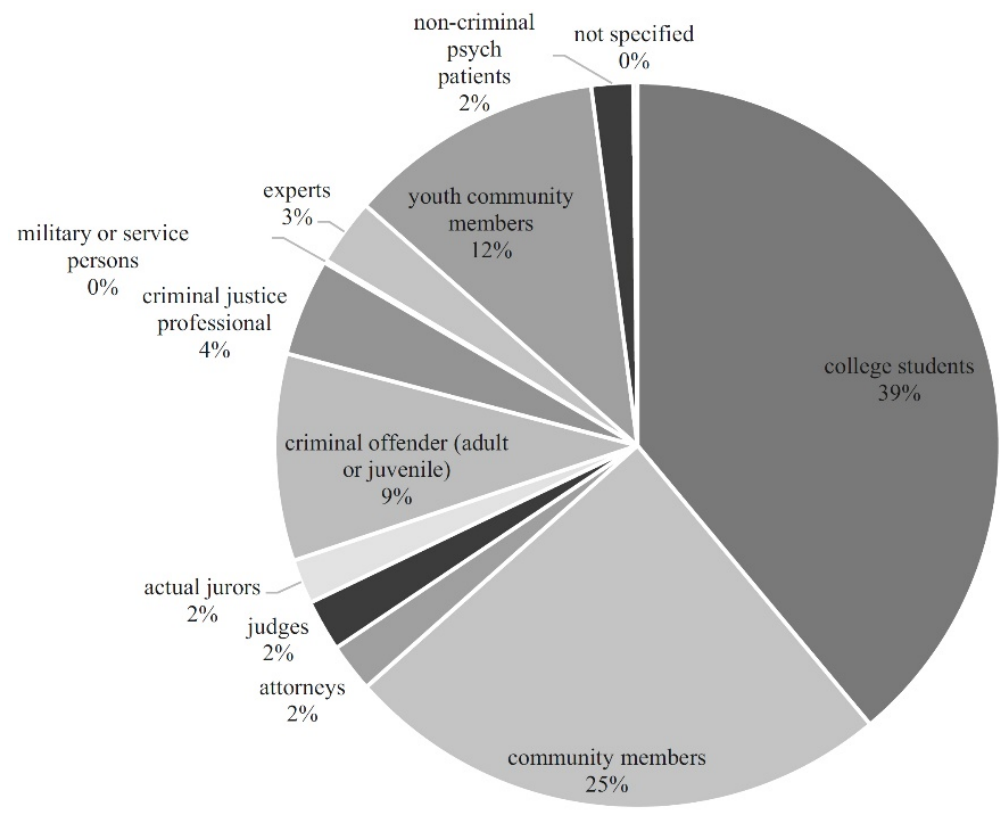

Figure 5. Type of sample within all coded samples.

Overall, the most prevalent type of sample was college student (39\%), which increased from the first to second decade but has remained consistent since then, $\chi^{2}(3)=26.61, p<.001$ (Fig. 6). Another $24.5 \%$ were adult community member participants, and $11.5 \%$ were youth community members, neither of which shifted over time, $\chi^{2}(3)=3.46, p=0.33$ and $\chi^{2}(3)=6.88, p=.08$, respectively. Only a few additional sample types demonstrated trends through $L H B^{\prime}$ s history (Fig. 6). The use of jurors increased from the first to second decade but then became less utilized in the third and fourth decade, $\chi^{2}(3)=9.86, p<.05$. The use of criminal offenders as participants has increased each decade since the second decade, $\chi^{2}(3)=47.17, p<.001$. Experts as participants has shifted such that there was an increase from the first to second decade but then a decline in the third, only to increase again in the most recent decade, $\chi^{2}(3)=10.56, p<.05$. Utilizing inpatient psychiatric patients in research increased from the first to second decade but has since had a steady decline into the most recent decade, $\chi^{2}(3)=11.55, p<.01$. 


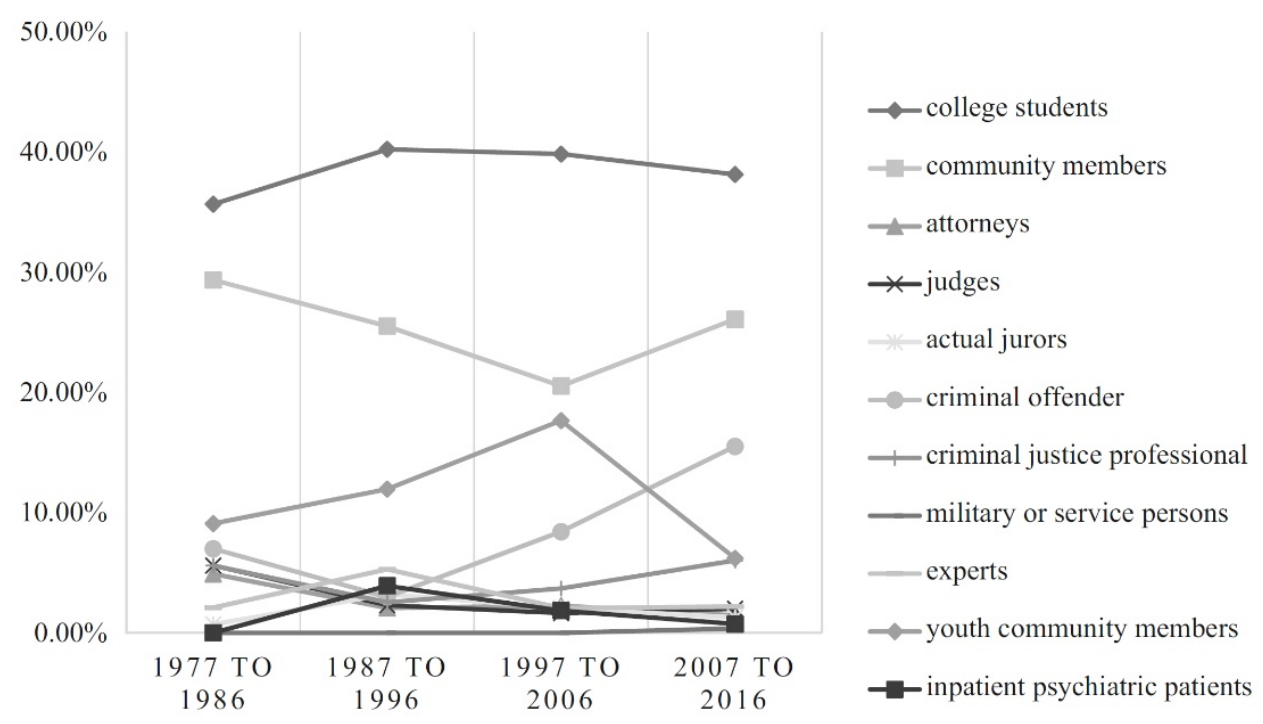

Figure 6. Sample type over time.

We also examined the types of samples within each research topic (Table 6). Although each sample type would not be appropriate for all research topics and the sample is dependent on the research question in each article, comparisons between samples that are relevant to the research can be made. Results indicated that $58.8 \%(n=218)$ of the samples from eyewitness/memory studies were college students, $23.7 \%$ were youth community members, $15.1 \%$ were community members, $1.1 \%$ were criminal justice professionals, $0.8 \%$ were judges, and $0.5 \%$ were attorneys. Similarly, $57.8 \%$ of the samples in articles about confessions and interrogations were college students, $21.1 \%$ were community members, $7.0 \%$ were criminal justice professionals, $7.0 \%$ were criminal offenders, and $5.6 \%$ were youth community members. Criminal jury/judicial decision-making was another area of research in which $52 \%$ of the samples from jury/judicial decision-making studies were college students, $32.5 \%$ were community members, $7 \%$ were actual jurors, and $3.7 \%$ were judges.

Next, we examined whether type of sample was related to Google Scholar citations and whether a court case cited the article. The only variable that had a significant bivariate relationship to Google Scholar citations was the inpatient sample type, $r(1360)=.07, p<.05$. Chi square analyses revealed a significant bivariate relationship for whether the article was cited by case law and the following samples: community members, $\chi^{2}(1)=4.27, p<.05$, criminal offenders, $\chi^{2}(1)=6.61, p<.05$, and youth community members, $\chi^{2}(1)=3.91, p<.05$; however, the remaining samples did not demonstrate a significant relationship. 


\begin{tabular}{|c|c|c|c|c|c|c|c|c|c|c|c|c|}
\hline Research area & $\begin{array}{c}\text { College } \\
\text { students } \\
(\%)\end{array}$ & $\begin{array}{c}\text { Community } \\
\text { members } \\
(\%)\end{array}$ & $\begin{array}{l}\text { Attorneys } \\
(\%)\end{array}$ & $\begin{array}{c}\text { Judges } \\
(\%)\end{array}$ & $\begin{array}{c}\text { Actual } \\
\text { jurors } \\
(\%) \\
\end{array}$ & $\begin{array}{c}\text { Criminal } \\
\text { offender } \\
(\%) \\
\end{array}$ & $\begin{array}{c}\text { Criminal } \\
\text { justice } \\
\text { professional } \\
(\%) \\
\end{array}$ & $\begin{array}{c}\text { Military/ } \\
\text { service } \\
\text { persons } \\
(\%) \\
\end{array}$ & $\begin{array}{c}\text { Experts } \\
(\%)\end{array}$ & $\begin{array}{c}\text { Youth } \\
\text { community } \\
\text { members } \\
(\%)\end{array}$ & $\begin{array}{l}\text { Inpatient } \\
\text { psychiatric } \\
\text { patients } \\
(\%)\end{array}$ & Total \\
\hline $\begin{array}{l}\text { Criminal jury/ } \\
\text { judicial }\end{array}$ & 52.0 & 32.5 & 1.9 & 3.7 & 7.0 & 0.0 & 0.0 & 0.0 & 2.3 & 0.7 & 0.0 & 431 \\
\hline Risk assessment & 11.4 & 14.3 & 0.0 & 0.0 & 0.0 & 28.6 & 5.7 & 0.0 & 20.0 & 2.9 & 17.1 & 35 \\
\hline Eyewitness/memory & 58.8 & 15.1 & 0.5 & 0.8 & 0.0 & 0.0 & 1.1 & 0.0 & 0.0 & 23.7 & 0.0 & 371 \\
\hline Law and policy & 22.2 & 53.0 & 0.0 & 0.0 & 0.0 & 0.0 & 3.0 & 0.0 & 0.0 & 18.2 & 0.0 & 66 \\
\hline Psychopathy & 13.3 & 13.1 & 0.0 & 0.0 & 2.2 & 42.2 & 8.9 & 0.0 & 11.1 & 4.4 & 4.4 & 45 \\
\hline Experts & 22.1 & 20.0 & 5.3 & 3.2 & 3.2 & 0.0 & 0.0 & 0.0 & 8.4 & 3.2 & 3.2 & 95 \\
\hline Corrections & 0.0 & 0.0 & 0.0 & 0.0 & 0.0 & 68.6 & 20.0 & 0.0 & 0.0 & 2.9 & 0.0 & 35 \\
\hline Sentencing & 43.3 & 40.3 & 1.5 & 9.0 & 0.0 & 0.0 & 0.0 & 0.0 & 0.0 & 6.0 & 0.0 & 67 \\
\hline $\begin{array}{l}\text { Police and } \\
\text { investigations }\end{array}$ & 33.7 & 19.4 & 0.0 & 0.0 & 0.0 & 7.1 & 21.3 & 0.0 & 2.0 & 15.3 & 1.0 & 98 \\
\hline Victims and trauma & 27.1 & 49.2 & 0.0 & 1.7 & 0.0 & 8.5 & 5.1 & 0.0 & 6.9 & 1.7 & 0.0 & 59 \\
\hline Juvenile justice & 9.1 & 15.2 & 2.0 & 3.0 & 0.0 & 37.4 & 9.1 & 0.0 & 2.0 & 21.2 & 1.0 & 99 \\
\hline $\begin{array}{l}\text { Mentally ill offenders } \\
\text { and patients }\end{array}$ & 5.9 & 14.1 & 2.4 & 1.2 & 1.2 & 41.2 & 7.1 & 0.0 & 14.1 & 0.0 & 12.9 & 85 \\
\hline Sex offenders & 11.1 & 0.0 & 11.1 & 0.0 & 11.1 & 33.3 & 0.0 & 0.0 & 22.2 & 11.1 & 0.0 & 9 \\
\hline $\begin{array}{l}\text { Courts and trial } \\
\text { procedure }\end{array}$ & 32.2 & 23.7 & 20.3 & 5.1 & 1.7 & 0.0 & 0.0 & 0.0 & 1.7 & 15.3 & 0.0 & 59 \\
\hline $\begin{array}{l}\text { Race/ethnicity } \\
\text { and gender }\end{array}$ & 41.2 & 19.1 & 4.4 & 5.9 & 1.5 & 13.2 & 7.4 & 0.0 & 0.0 & 2.9 & 4.4 & 68 \\
\hline $\begin{array}{l}\text { Competency and } \\
\text { criminal } \\
\text { responsibility }\end{array}$ & 17.5 & 19.6 & 2.1 & 1.0 & 3.1 & 33.0 & 0.0 & 0.0 & 3.1 & 13.4 & 7.2 & 97 \\
\hline Family issues & 0.0 & 55.6 & 11.1 & 11.1 & 0.0 & 0.0 & 0.0 & 0.0 & 11.1 & 11.1 & 0.0 & 18 \\
\hline Alternatives to court & 10.5 & 31.6 & 5.3 & 15.8 & 0.0 & 21.1 & 5.3 & 0.0 & 10.5 & 0.0 & 0.0 & 19 \\
\hline General law-psych & 0.0 & 50.0 & 0.0 & 0.0 & 0.0 & 0.0 & 0.0 & 0.0 & 0.0 & 50.0 & 0.0 & 4 \\
\hline Death penalty & 33.3 & 51.3 & 0.0 & 0.0 & 12.8 & 0.0 & 2.6 & 0.0 & 0.0 & 0.0 & 0.0 & 39 \\
\hline
\end{tabular}


WYLIE ET AL., SCIENTOMETRICS 115 (2018)

\begin{tabular}{|c|c|c|c|c|c|c|c|c|c|c|c|c|}
\hline Research area & $\begin{array}{c}\text { College } \\
\text { students } \\
(\%) \\
\end{array}$ & $\begin{array}{c}\text { Community } \\
\text { members } \\
(\%)\end{array}$ & $\begin{array}{c}\text { Attorneys } \\
(\%)\end{array}$ & $\begin{array}{c}\text { Judges } \\
(\%) \\
\end{array}$ & $\begin{array}{c}\text { Actual } \\
\text { jurors } \\
(\%) \\
\end{array}$ & $\begin{array}{c}\text { Criminal } \\
\text { offender } \\
(\%) \\
\end{array}$ & $\begin{array}{c}\text { Criminal } \\
\text { justice } \\
\text { professional } \\
(\%) \\
\end{array}$ & $\begin{array}{c}\text { Military/ } \\
\text { service } \\
\text { persons } \\
(\%) \\
\end{array}$ & $\begin{array}{c}\text { Experts } \\
(\%)\end{array}$ & $\begin{array}{c}\text { Youth } \\
\text { community } \\
\text { members } \\
(\%) \\
\end{array}$ & $\begin{array}{l}\text { Inpatient } \\
\text { psychiatric } \\
\text { patients } \\
(\%) \\
\end{array}$ & Total \\
\hline Sexual harassment & 39.3 & 53.6 & 3.6 & 0.0 & 0.0 & 0.0 & 0.0 & 3.6 & 0.0 & 0.0 & 0.0 & 28 \\
\hline $\begin{array}{l}\text { Criminal offending } \\
\text { and recidivism }\end{array}$ & 9.1 & 36.4 & 0.0 & 0.0 & 0.0 & 50.0 & 0.0 & 0.0 & 0.0 & 4.6 & 0.0 & 22 \\
\hline $\begin{array}{l}\text { Lie deception } \\
\text { and detection }\end{array}$ & 39.3 & 7.9 & 0.0 & 0.0 & 0.0 & 3.4 & 21.4 & 0.0 & 1.1 & 2.7 & 0.0 & 89 \\
\hline $\begin{array}{c}\text { Confessions and } \\
\text { interrogations }\end{array}$ & 57.8 & 21.1 & 0.0 & 1.4 & 0.0 & 7.0 & 7.0 & 0.0 & 0.0 & 5.6 & 0.0 & 71 \\
\hline Child maltreatment & 44.1 & 20.6 & 0.0 & 0.0 & 2.9 & 2.9 & 0.0 & 0.0 & 5.9 & 23.5 & 0.0 & 34 \\
\hline Pretrial publicity & 47.6 & 33.3 & 4.8 & 4.8 & 0.0 & 0.0 & 0.0 & 0.0 & 9.5 & 0.0 & 0.0 & 21 \\
\hline Civil commitment & 7.1 & 14.3 & 7.1 & 7.1 & 7.1 & 28.6 & 7.1 & 0.0 & 0.0 & 0.0 & 21.4 & 14 \\
\hline Procedural justice & 8.3 & 58.3 & 0.0 & 8.3 & 0.0 & 8.3 & 0.0 & 0.0 & 8.3 & 8.3 & 0.0 & 24 \\
\hline Miranda rights & 28.6 & 14.3 & 0.0 & 0.0 & 0.0 & 33.3 & 4.8 & 0.0 & 0.0 & 14.3 & 4.8 & 21 \\
\hline Domestic violence & 77.8 & 11.1 & 0.0 & 0.0 & 0.0 & 11.1 & 0.0 & 0.0 & 0.0 & 0.0 & 0.0 & 9 \\
\hline Civil damages & 51.0 & 34.7 & 0.0 & 2.0 & 4.1 & 0.0 & 0.0 & 0.0 & 8.2 & 0.0 & 0.0 & 49 \\
\hline
\end{tabular}

Includes 1616 samples, but samples may have been counted up to twice if two research areas were coded for a particular article. 
Next, a regression equation was estimated with the total number of samples and each sample type dummy coded ( 1 = sample type present in the article), which yielded a significant model, $F(12,1075)=20.86, p<.001, R^{2}=0.19$; however, the only significant variables was publication year. Neither the number of samples, nor any of the sample types significantly predicted Google Scholar citations. A logistic regression was estimated to predict whether sample type predicted whether an article was cited by a court case, which was statistically significant, $\chi^{2}(12)=65.97, p<.001, R^{2}=.06$, and correctly classified $90.2 \%$ of cases. As with the Google Scholar citations regression, only year was a significant predictor and neither number of samples, nor any of the sample types significantly predicted case law citations.

\section{Sample characteristics}

Next, we examined specific sample characteristics for the samples that included human participants that provided age and race/ethnicity demographic information $(n=1616$; Table 7$)$. A total of 864 articles included mean age. The overall mean age of all the samples was 26.32 (SD $=12.56$ ) with individual study mean ages that ranged from 1.62 (a study that interviewed children about medical emergencies) to 78.50 (a study measuring older adults as eyewitnesses). Across sample types, studies that included judges and experts were most likely to utilize older samples. Overall, however, few studies included older samples. In examining age by research topic, five studies $(<.1 \%)$ included samples with a mean age greater than 65 years old. Of these studies, four of them were studies on eyewitnesses/memory and one involved mental health issues and corrections. Contrast this with the number of studies $(n=187 ; 11.6 \%)$ that included children under the age of 18 . 


\begin{tabular}{|c|c|c|c|c|c|c|c|c|c|}
\hline \multirow[b]{2}{*}{ Sample } & \multicolumn{5}{|c|}{ Age } & \multicolumn{4}{|c|}{ Race } \\
\hline & $N$ & $M$ & $S D$ & Min & Max & $N$ & $\begin{array}{c}\% \\
\text { mostly } \\
\text { White }\end{array}$ & $\begin{array}{c}\text { \% equal } \\
\text { or mostly } \\
\text { nonwhite }\end{array}$ & $\begin{array}{c}\% \text { not } \\
\text { enough } \\
\text { info }\end{array}$ \\
\hline College students & 252 & 21.34 & 2.61 & 18.23 & 31.28 & 612 & 16.4 & 7.2 & 76.5 \\
\hline $\begin{array}{l}\text { Community } \\
\text { members }\end{array}$ & 227 & 36.72 & 9.08 & 18.00 & 78.50 & 372 & 38.6 & 6.6 & 54.8 \\
\hline Attorneys & 10 & 37.31 & 7.17 & 27.10 & 49.21 & 34 & 25.7 & 0.0 & 74.3 \\
\hline Judges & 9 & 50.65 & 4.45 & 43.21 & 56.79 & 36 & 18.9 & 0.0 & 81.1 \\
\hline Actual jurors & 11 & 43.67 & 2.62 & 39.25 & 48.00 & 30 & 43.8 & 3.1 & 53.1 \\
\hline $\begin{array}{l}\text { Criminal } \\
\text { offenders }\end{array}$ & 115 & 28.78 & 8.82 & 14.52 & 46.16 & 143 & 36.9 & 40.9 & 22.2 \\
\hline $\begin{array}{c}\text { Criminal justice } \\
\text { professionals }\end{array}$ & 44 & 35.46 & 7.09 & 20.80 & 46.30 & 68 & 12.9 & 15.7 & 71.4 \\
\hline $\begin{array}{l}\text { Military or service } \\
\text { persons }\end{array}$ & 2 & - & - & - & - & 2 & 0.0 & 0.0 & 100.0 \\
\hline Experts & 10 & 48.00 & 4.34 & 40.70 & 55.00 & 45 & 16.7 & 0.0 & 83.3 \\
\hline $\begin{array}{l}\text { Youth community } \\
\text { members }\end{array}$ & 161 & 9.05 & 3.86 & 1.62 & 18.60 & 181 & 46.0 & 8.7 & 45.4 \\
\hline $\begin{array}{r}\text { Psychiatric } \\
\text { inpatient }\end{array}$ & 25 & 36.29 & 7.57 & 16.00 & 55.30 & 30 & 53.3 & 23.3 & 23.3 \\
\hline Total & 864 & 26.32 & 12.56 & 1.62 & 78.50 & 1553 & 28.5 & 10.4 & 61.2 \\
\hline
\end{tabular}

No age information was included for military/service persons.

For the articles that specified a numerical percentage for race/ethnicity, we calculated the mean for that race and/or ethnicity and indicated the number of articles that reported the percentage of the sample that identified as that race/ethnicity. The overall mean for the six racial and/or ethnic groups were as follows: White $(M=65.77 \%, S D=26.42, n=556)$, Black $(M=$ $19.19 \%, S D=20.01 ; n=390)$; Latino/Hispanic $(M=15.72 \%, S D=22.10 ; n=343)$, Asian $(M=$ $6.81 \%, S D=11.95 ; n=269)$, Middle Eastern $(M=0.45 \%, S D=1.78 ; n=126)$, and Native American $(M=1.19 \%, S D=3.75 ; n=163)$. Some articles did not include numerical percentages but instead included language such as "mostly White" or "equal or mostly non-White." To include these articles as well, we also examined sample race/ethnicity categorically. A total of 626 articles that specified a type of sample included participant racial or ethnic information. A large proportion of articles were coded as not having enough racial or ethnic information $(n=991)$, though this did vary by type of sample. For instance, race/ethnicity was more commonly reported for inpatient psychiatric patients and criminal offenders, but less often so for experts and judges. We examined this categorical variable over time and found that while not reporting enough information about race has declined each decade, articles using samples that were "mostly White" and equal or "mostly non-White" increased. Articles reporting "mostly White" increased from the second to third decade; articles reporting equal or "mostly non-White" increased from decades two through four, $\chi^{2}(6)=124.30, p<.001$. Figure 7 illustrates whether 
authors reported age and race/ethnicity, as well as whether the sample was mostly White or equal/mostly non-White.

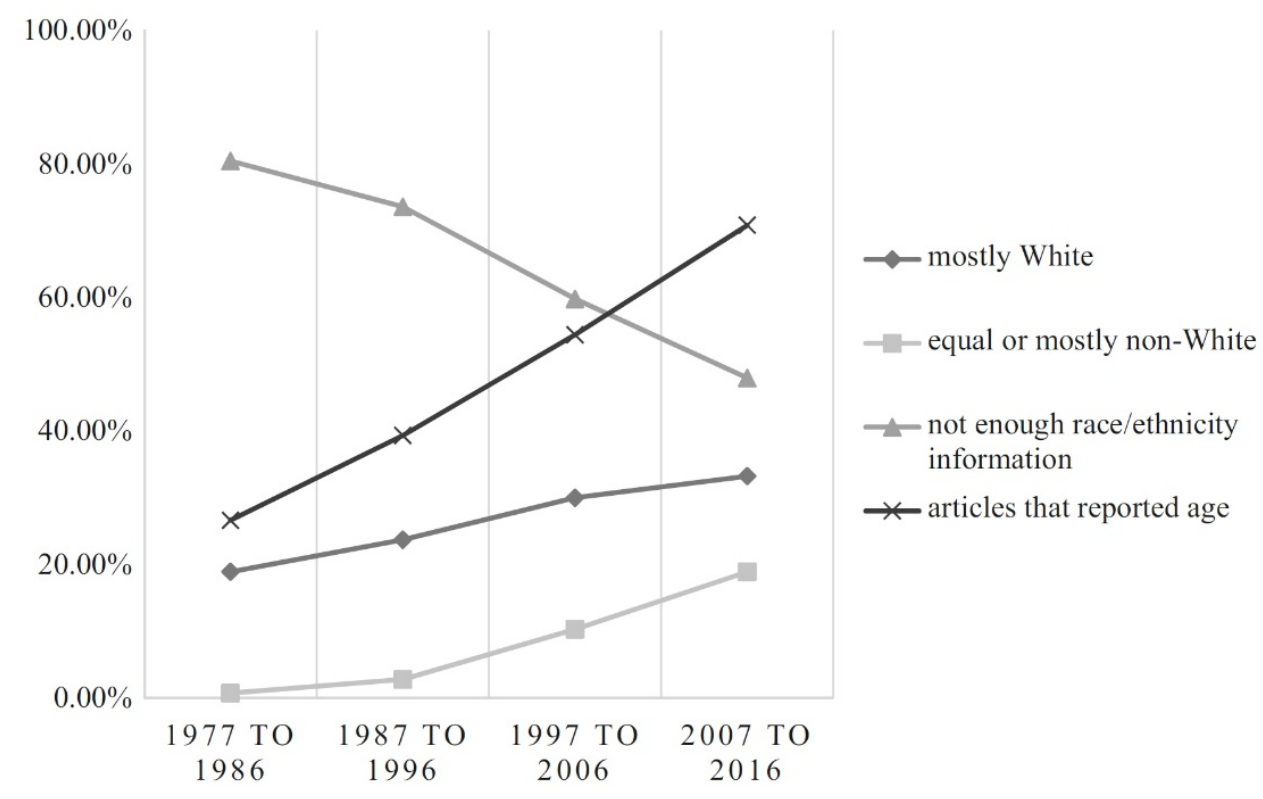

Figure 7. Proportion of articles over time that reported race and age, and whether the samples that were reported were mostly White or mostly non-White.

\section{Online samples}

We also recorded whether any samples were online samples. The earliest study published in LHB that utilized an online sample was in 2002 and was an article studying pretrial publicity effects using online samples as a new method (Studebaker et al. 2002). Of the articles that utilized human participants, 32 articles (2.4\%) reported utilizing an online sample (a total of 55 samples). The samples were drawn from the following sites/methods: Amazon's Mechanical Turk $(n=31)$, Listservs specific to the sample's field $(n=3)$, Study-Response $(n=2)$, a public opinion research firm $(n=4)$, social networking $(n=1)$, survey monkey panel $(n=2)$, Timesharing Experiments for the Social Sciences (TESS; $n=1)$, Knowledge Networks $(n=2)$, Craigslist $(n=1)$, midgame.com (Israel, $n=4)$, Yahoo and Four11 email search engine $(n=1)$, and three were not specified. We did not include trends over time or whether online samples predicted citations in the regression models because there were relatively few articles with online samples and they were mostly recent articles.

\section{Combined analysis}

To develop final models for predicting article impact on Google Scholar citations and case law citations, all variables that significantly predicted each were combined into a single model for each citation index (Table 8). The Google Scholar citation regression was significant, $F(19,1297)$ $=25.37 p<.001, R^{2}=0.27$. Most predictors remained significant including year of publication 
(centered at 1997), the gender 9 year interaction, number of authors, all eight research topics (criminal jury/judicial decision-making, eyewitness/ memory, competency/criminal responsibility, mentally ill offenders/psychiatric patients, risk assessment, lie detection/deception, psychopathy, and criminal offending and recidivism), whether the article was coded as a research methods article or law only article under area of psychology, length of article, length of title, and whether a colon was used in the title. The variables no longer significant were first author gender and two research topics (Miranda, and law and policy).

Table 8. Summary of overall multiple regression analysis predicting impact

\begin{tabular}{|c|c|c|}
\hline Predictor & $\begin{array}{c}\text { Google scholar citations } \\
\beta\end{array}$ & $\begin{array}{c}\text { Case law citations } \\
\operatorname{Exp}(\beta)\end{array}$ \\
\hline Criminal jury/judicial & $0.13^{* * *}$ & $2.63^{* * *}$ \\
\hline Death penalty & - & $5.20^{* * *}$ \\
\hline Eyewitness/memory & $0.17^{* * *}$ & $6.54^{* * *}$ \\
\hline Risk assessment & $0.13^{* * *}$ & - \\
\hline Competency/criminal resp. & $0.06^{*}$ & - \\
\hline Mentally ill offenders/psych. patients & $0.09^{* *}$ & - \\
\hline Criminal offending/recidivism & $0.08^{* * *}$ & - \\
\hline Lie detection/deception & $0.14^{* * *}$ & - \\
\hline Miranda & 0.04 & $4.82^{*}$ \\
\hline Psychopathy & $0.09^{* * *}$ & - \\
\hline Law and policy & -0.04 & - \\
\hline Experts & - & 0.60 \\
\hline Confessions and Interrogations & - & $9.10^{* * *}$ \\
\hline Research methods & $0.06^{* *}$ & - \\
\hline Law only & $-0.07^{* *}$ & - \\
\hline Clinical & - & 0.77 \\
\hline Developmental & - & 0.43 \\
\hline Year & $-0.25^{* * *}$ & $0.96^{* *}$ \\
\hline Author gender & 0.05 & 0.67 \\
\hline Year $\times$ author gender & $-0.20^{* * *}$ & $0.91^{* * *}$ \\
\hline Number of authors & $0.07^{* * *}$ & - \\
\hline Article length (pages) & $0.26^{* * *}$ & $1.03^{* *}$ \\
\hline Title length (words) & $-0.07^{* *}$ & - \\
\hline Colon in title & $0.10^{* * *}$ & $2.038^{* *}$ \\
\hline
\end{tabular}

${ }^{* * *} p<.001 ; * * p<.01 ; * p<.05$

- Indicates it was not included in the model

The logistic regression predicting whether an article was cited by case law was statistically significant, $\chi^{2}(10)=183.08, p<.001, R^{2}=.13$ and correctly classified $89.8 \%$ of cases. Clinical psychology, developmental psychology, author gender, one of the research topics (experts) were no longer significant in this final model. The remaining variables significantly predicted whether an article was cited by case law including the year $\times$ author gender interaction, five 
research areas (jury/judicial decision-making, eyewitness/ memory, death penalty, confessions and Miranda), length of article, and whether there was a colon in the title.

\section{Discussion}

As $L H B$ has recently marked the end of four decades of publications, it is an ideal time to assess where the journal has been and how it may grow in the future. In the current research, we employ Scientometrics methods to systematically examine the publication history of $L H B$ from 1977 to 2016 with two over-arching goals in mind. The first was to examine trends in $L H B$ over the last 40 years to document the diversity of the research scholarship, as a means for inspiring future research. The second was to model what factors are most influential in determining citation patterns so that consumers and producers of research can see what areas are having the most impact thus far.

Overall, $L H B$ published articles from diverse topics related to both psychology and law, which are being cited in other journals and the courts. On average, $L H B$ articles are being cited approximately 65 times, with almost one-fifth of the articles reaching 100 Google Scholar citations or more. The vast majority of articles citing to $L H B$ articles are published in journals other than $L H B$, which suggests that articles in $\angle H B$ are making an impact beyond itself and other outlets. Notably, $10 \%$ of the articles were cited within case law, across several different research topics including jury/judicial decision-making, eyewitness memory, sentencing, and police interactions. Articles that are making extremely high numerical impact are the White Papers published on specific topics (i.e., eyewitness memory best practices and police-induced confessions), as well as articles that compare methods within a particular research area (e.g., comparing three actuarial scales for sex offenders, comparing jury/judicial decision-making methods).

Analyses revealed a shift toward more diverse first authors, as well as a year $\times$ gender interaction for both citation indices, and significant main effect of gender for Google Scholar citations. LHB trends in authorship diversity likely mirror the diversity trends across academic literature more generally with more women (Christidis et al. 2014; McCann et al. 2017) and non-US authors publishing in LHB as first authors (Kliegl and Bates 2010; Ogloff 2000). Type of affiliation has largely remained consistent over time as most first authors came from academic institutions that are classified as a doctoral highest research level, which is not surprising considering the research demands and expectations at these institutions.

Although $L H B$ editors have historically made calls for diversification, particularly regarding research topics and legal emphases (Saks 1986), 37\% of the articles included topics related to jury/judicial decision-making and eyewitnesses/memory, three-fourths of the articles were rooted in criminal law or mental health law, and two-thirds of the articles published stemmed from social-cognitive psychology. Over time, some research topics did shift. For instance, sentencing, the role of experts, and law and policy composed a large percentage of the research in the first decade but then declined into the second decade. Clinical psychology publications increased, as Roesch had encouraged; however, the largest increase was not until the third to most recent decade. And, of the two most common research areas, while eyewitness/memory 
remained stable throughout, there was a steep decline in criminal jury/judicial decision-making research from the third to the fourth decade.

Despite the calls for diverse research, however, these findings do demonstrate value in studying topics in more depth. For instance, two of the most prevalent research areas, eyewitness memory and jury/judicial decision-making, are most often cited by courts and have the highest number of citations in general. The benefit of focusing on fewer areas means that studies are replicated, and findings may be more nuanced. Perhaps this narrow but deeper focus in these two areas is the reason other articles and the courts are more likely to cite these articles.

Another domain with room to grow is including more diverse samples. As noted, college students composed approximately $40 \%$ of the samples and composed more than half of the samples for articles on confessions and interrogation, eyewitness/memory, and domestic violence and close to half of the samples for articles about jury/judicial decision-making, pretrial publicity, victims and trauma, sentencing, civil damages, and on race/gender issues. Within jury decision-making research, Bornstein (1999) published a comprehensive review of jury studies published in $L H B$ to examine whether there were any systematic differences between mock jurors and actual jurors. His conclusion that, "few differences ... as a function of ... who the mock juror is" (p. 88) has been widely cited and clearly contributes to the proliferation of student samples. However, there are some practical implications that should give scholars pause in this area. Courts have hesitated to welcome psycho-legal research findings, especially when student samples are used (Diamond 1997). The number of citations in court cases to articles with student samples was less, though not statistically significant, than the number of citations in court cases to articles with other samples $(n=98)$. Notwithstanding the debate to use or not use college students, as a field, we are neglecting some key legal actors and decision-makers. Less often utilized samples included criminal justice professionals, judges, and attorneys, which are samples that could offer a unique perspective on research topics currently studied or on emerging research topics.

Although early research did not often provide demographic information about the samples, authors have more consistently reported this information in recent years. Despite this improvement, a large proportion did not report specific race/ethnicity information or mean age. Because of inconsistent reporting, it is unclear whether samples have become more diverse in terms of race/ethnicity and age. For studies that reported race and ethnicity, there does appear to be an increase in racial/ethnic diversity in recent years. This diversity, however, may be the result of outside forces other than researchers' choice. For instance, the samples that exhibited the most racial/ethnic diversity were criminal offenders and those that were in psychiatric inpatient hospitals. Although on one hand this racial/ethnic composition may be representative of the population studied and may reflect that the information was more readily available (these two samples have the lowest reported "not enough information"), it importantly highlights the lack of racial/ethnic diversity (or lack of reporting) in other samples such as with college students and community members. Similarly, very few studies reported samples that included older adults. Those samples that did include older adults often did so because of the specific sample being used (i.e., judges) and not a choice of the researchers to study older adults in particular. 
Up to this point, only 32 articles used purely online samples. A common argument for using online samples is that the sample will be more diverse. Because far fewer studies used online samples than not, we did not compare the demographic information for online versus nononline samples. This, however, may be an interesting future direction, especially if trends continue to increase in favor of using online samples such as Amazon's Mechanical Turk. Of course, this could mean more diversity, especially in terms of geography, but courts may be reluctant to hear research that was conducted online because of concerns with ecological validity. The current data could not adequately examine this issue because even though courts have cited articles as far back as 1977, they have not yet cited any articles with online samples, which could be due to the recency of the online articles.

\section{Limitations}

Although we chose to focus only on $L H B$ rather than the larger scope of all psychology and law journals, we did code all of the relevant articles in $L H B$. A focus on only $L H B$ rather than a sampling of several journals does not allow for comparisons across journals. Nonetheless, we chose to employ a full population of articles rather than a sample to avoid missing low frequency occurrences. Using the full population of articles provides a clear picture of the publishing trends in the longest published law-psychology journal. Another limitation of this analysis is the subjectivity of the coding. Although we took measures to ensure inter-rater reliability for coding, there were subjective decisions made in terms of the variables chosen for coding and the categories within each variable. In coding research topics, we chose to use indicative and deductive approaches for coding research topics, which resulted in both broader categories and the most frequent specific topics or psychological/legal theories (e.g., procedural justice, false confessions). While this allowed for parsimony in data analysis, future research may include more in-depth analyses within a specific research topic.

One clear limitation of this work is that we were only able to code those articles that were published and not the full set of articles that were submitted to LHB. This does pose a selection bias issue because we do not have a full picture of the type of research being conducted. Nonetheless, the editorial policy of $L H B$ has consistently focused on the scholarship quality and not the specific topics, which means in order to increase the diversity across domains in $L H B$, scholars need to do excellent research and submit their work for consideration. It is impossible to know with the current data whether the editorial calls for diversity had an impact. Not only does it take time for the research community to fulfill the call because of the time it takes to design, implement, and publish research, there are also many external factors other than editorial calls that inspire research projects and drive publication trends. For example, current events, case law, and psychological theory trends are all likely to influence why a researcher tackles a certain topic. Although we cannot know whether the editorial calls had an impact, we do have a clear picture of what research has been done in $L H B$. Any future calls for diversity can be based on the foundation of empirical research that provides a clear picture of the research that has been published in $L H B$. 
As noted in Grisso (1991) with reference to the first newsletter for AP-LS, "We can perceive that we have taken on a precious responsibility, for there are few interdisciplinary areas with so much potential 'as psychology and law' for improving the human condition and for acquiring and utilizing greater understanding of man." Such diversity of research pushes the field toward greater possibilities of improving the human condition in even more areas (see Grisso 1991). Editors Saks (1986) and Roesch (1990) both asserted that the research that has been done and published in $L H B$ should have been done. Yet, there are many other areas to be examined. As Bruce Sales pointed out (as cited in Saks 1986), "virtually all laws rest upon a base of behavioral assumptions; the validity and utility of those laws depend in part upon the accuracy of those behavioral assumptions" (p. 280).

\section{Conclusion}

The current study is the first of its kind to examine systematically the entire history of research articles published in $L H B$. Not only do the results provide an overview of the topics addressed by the research published in $\angle H B$ and the researchers writing those articles, the results also provide a succinct picture of the way those topics and authors have changed over time, what factors predict citations, and how often the courts use the articles. Although there have been several calls to diversity this analysis demonstrates some of those calls have been heard. LHB is relatively diverse and seems to be moving in the direction of even more diversity. We hope this is a source of excitement to researchers as $L H B$ enters its fifth decade because there are many untapped topics and areas of psychology and law. 
WYLIE ET AL., SCIENTOMETRICS 115 (2018)

\begin{abstract}
Appendix
Risk assessment

Included anything about predicting future violence or dangerousness. This category may have included use of specific risk assessment tools (e.g., SAVRY) or factors predicting risk more generally. If an article discussed risk assessment in terms of more specific population, such as sex offenders or psychopathy, then both categories were coded.

Competency and insanity

Included anything related to assessing competency (in both criminal and civil domains) or insanity. This category also included use or validation of specific assessment tools (e.g., Mac-CAT). If an article discussed clinical assessment of psychopathy (or sex offenders), then both clinical assessment and psychopathy (or sex offenders) were coded. If an article included a jury decision-making study where a primary focus was on the defendant's mental state or mental health, then both competency and insanity, and jury decision-making were coded.

\section{Criminal offending and recidivism}

Civil commitment

Police and investigations

Lie/deception detection

Confessions and interrogations

Eyewitness/memory

Court and trial procedures

Jury or judicial decision-making

Included topics related to civil commitment.

Included anything related to criminal offending in general or research examining recidivism/reoffending.

Included topics related to investigation and police behavior more generally. This category included topics such as forensic evidence/science, criminal profiling, investigative interviewing, and consenting to a search. If the article also specifically examined Miranda warnings, we also coded Miranda warnings separately.

Included articles on both experts' and laypersons' abilities to detect lies as well as polygraph testing.

Included articles specifically examining confessions, false confessions, and interrogation techniques.

Included anything related to lineup identification, memory, eyewitness confidence, perceptions of eyewitnesses, and earwitnesses.

Included articles that related to specific processes within the courts as well as the effects of certain court matters, such as change of venue or effects of joinder.

Included articles with jurors, juries, or judges making decisions. Within this category, a second category was coded that related more specifically to the type of decisions made. For instance, if the study was about deathqualified jurors, then jury/judicial decision-making and death penalty were coded. If the study involved perceptions of attorney behavior, then jury/judicial decision-making and the court and trial procedures was coded. If the study involved the effects of eyewitness testimony on juries, then jury/judicial decision-making and eyewitness memory were both coded. To examine whether there were differences for civil jury decisions and criminal, we also coded for whether the study specifically examined Civil Damages. We also coded for studies that specifically examined pretrial publicity.
\end{abstract}


WYLIE ET AL., SCIENTOMETRICS 115 (2018)

\begin{tabular}{l} 
Appendix continued \\
\hline Sentencing and pleas \\
Alternatives to court \\
Corrections \\
Psychopathy \\
Sex offenders \\
Mentally ill offenders and \\
psychiatric patients
\end{tabular}

Victims and trauma

Experts' roles

Race/ethnicity and gender

Juvenile justice

Family issues

Procedural justice
Included articles about sentencing offenders, such as factors relating to sentencing and punishment. This variable also included plea bargaining. We coded anything related to the death penalty separately under Death Penalty.

Included articles focused on mediation, arbitration, other alternative dispute resolutions, or problem-solving courts.

Included any articles that focused on institutional corrections (e.g., prisons, jails) and community corrections (e.g., probation).

Included content that had anything to do with psychopathy, treatment of psychopathy, or assessment of psychopathy.

Included content that had anything to do with sex offenders or treatment of sex offenders.

Included topics such as treatment of mentally ill offenders, perceptions of people with mental illness, or issues in general mental health law. If an article was specifically about the mental health and prison/jail or probation, then both mentally ill offenders and psychiatric patients, and corrections were coded.

Included anything related to victims (e.g., rape, trauma). If the article discussed police interaction with victims, then both victims and police interactions were coded. We coded anything related to child maltreatment and domestic violence into two additional variables, respectively.

Included topics related to various experts relevant to psychology and law including expert witnesses, advocates, clinicians, lawyers, or psychology law/legal education. If an article included discussion on experts testifying about a particular area (e.g., expert witnesses testifying about eyewitness memory), then the substantive area was also coded (e.g., eyewitness/ memory). This also included ethical issues for researchers including informed consent and clinician's duty to report (i.e., Tarasoff $v$. Regents of the University of California 1976).

This category was selected if the study included race/ethnicity or gender as a primary variable of interest. This often included a study with a primary area of interest (e.g., police and investigations, eyewitness memory) and the effects of race or gender within that area. This category also included studies such as discrimination based on gender or race. Sexual harassment was coded as a separate variable.

Included anything related to juvenile criminal law or juvenile offenders. This category did not include youth as witnesses, victims, and other noncriminal settings such as custody disputes.

Included issues related to divorce, custody, family relationships, minors' rights to privacy, and youths' right to consent (in noncriminal settings).

Included any articles that specifically examined procedural justice (i.e., perceptions of legal institutions or legal actors under procedural justice theory). 


\begin{tabular}{ll}
\hline Appendix continued & \\
\hline Law and policy & Although public policy can be a catch-all category, every effort was made \\
& to stay within public policy defined by Kilpatrick (2000) "as a system of \\
laws" (e.g., traffic law issues), "regulatory measures" (e.g., medical field & regulations, vaccines), "or legal system courses of actions" (e.g., wrongful \\
conviction compensation) (p. 1). This category also included more specific \\
analysis of statutes, noncriminal Constitutional issues such as speech, re- \\
ligion, or voting rights. Criminal Constitutional issues were coded within \\
the more specific area and not within public policy (e.g., consenting to \\
search was coded within police interactions). Issues related to discrimina- \\
tion were coded within race/ethnicity gender and not within public policy. \\
An article was coded under general psychology and law if it was a general \\
review or discussion of psychology and law, related to teaching of psy- \\
chology and law, discussed an over-arching theory as it applied to psy- \\
chology and law, discussed empirical methods in general (i.e., does not \\
include empirical methods applied to a specific area such as eyewitnesses \\
or juries), issues related to sharing data or data confidentiality, or applied \\
to broad area such as the courts or use of the law.
\end{tabular}

\section{References}

Adair, J. G., \& Vohra, N. (2003). The explosion of knowledge, references, and citations: Psychology's unique response to a crisis. American Psychologist, 58, 15-23. https://doi.org/10.1037/0003-066x.58 .1.15.

APA (American Psychological Association). (2017). Law and Human Behavior. Retrieved February 28, 2017, from http://www.apa.org/pubs/journals/lhb/.

AP-LS. (2017). American Psychology-Law Society. http://www.apadivisions.org/division-41/index.aspx.

Appelbaum, P. S., \& Grisso, T. (1995). The MacArthur Treatment Competence Study. I: Mental illness and competence to consent to treatment. Law and Human Behavior, 19(2), 105.

Baker, L. A., \& Emery, R. E. (1993). When every relationship is above average: Perceptions and expectations of divorce at the time of marriage. Law and Human Behavior, 17(4), 439.

Bailey, C. E., Pryce, J., \& Walsh, F. (2002). Trends in author characteristics and diversity issues in the Journal of Marital and Family Therapy from 1990 to 2000. Journal of Marital and Family Therapy, 28, 479-485. https://doi.org/10.1111/j.1752-0606.2002.tb00372.x.

Barrios, M., Villarroya, A., \& Borrego, Á. (2013). Scientific production in psychology: A gender analysis. Scientometrics, 95, 15-23. https://doi.org/10.1077/s11192-012-0816-4.

Bornstein, B. H. (1999). The ecological validity of jury simulations: Is the jury still out? Law and Human Behavior, 23(1), 75-91. https://doi.org/10.1023/a:1022326807441.

Bornstein, B. H., \& Penrod, S. D. (2008). Hugo who? G. F. Arnold's alternative early approach to psychology and law. Applied Cognitive Psychology, 22, 759-768. https://doi.org/10.1002/acp.1480.

Bornstein, B. H., Wiener, R. L., \& Maeder, E. M. (2008). Pioneers in interdisciplinary legal education: A history of the UNL law-psychology program. In A. G. Gless (Ed.), The history of Nebraska law (pp. 174194). Athens, OH: Ohio University Press. 
Christidis, P., Wicherski, M., Hamp, A., Stamm, K. \& Nigrinis, A. (2014, October). How is the gender composition of faculty in graduate psychology departments changing? American Psychological Association Monitor on Psychology, 45, 11. Retrieved February 28, 2017, from https://www.apa.org/ monitor/2014/10/datapoint.aspx.

Cikara, M., Rudman, L., \& Fiske, S. (2012). Dearth by a thousand cuts? Accounting for gender differences in top-ranked publication rates in social psychology. Journal of Social Issues, 68, 263-285.

Cohen, J. (1960). A coefficient of agreement for nominal scales. Educational and Psychology Measurement, 20, 37-46. https://doi.org/10.1177/001316446002000104.

Cutler, B. L. (2007). Editor's note. Law and Human Behavior, 31, 1-2. https://doi.org/10.1007/s10979-0069085-1.

Deffenbacher, K. A., Bornstein, B. H., \& Penrod, S. D. (2006). Mugshot exposure effects: Retroactive interference, mugshot commitment, source confusion, and unconscious transference. Law and Human Behavior, 30, 287-307. https://doi.org/10.1007/s10979-006-9008-1.

Deffenbacher, K. A., Bornstein, B. H., Penrod, S. D., \& McGorty, E. K. (2004). A meta-analytic review of the effects of high stress on eyewitness memory. Law and Human Behavior, 28, 687-706. https://doi.org/10.1007/s10979-004-0565-x.

Delgado-Romero, E. A., Galván, N., Maschino, P., \& Rowland, M. (2005). Race and ethnicity in empirical counseling and counseling psychology research: A 10-year review. The Counseling Psychologist, 33, 419-448. https://doi.org/10.1177/0011000004268637.

Devine, D. J., Clayton, L. D., Dunford, B. B., Seying, R., \& Pryce, J. (2000). Jury decision making: 45 years of empirical research on deliberating groups. Psychology, Public Policy, and Law, 7(3), 622-727. https://doi.org/10.1037/1076-8971.7.3.622.

Diamond, S. S. (1997). Illuminations and shadows from jury simulations. Law and Human Behavior, 21, 561-571. https://doi.org/10.1023/a:1024831908377.

Dillon, J. Y. (1981). The emergence of the colon: An empirical correlate of scholarship. American Psychologist, 36, 879-884. https://doi.org/10.1037/0003-066x.36.8.879.

Elo, S., \& Kyngäs, H. (2008). The qualitative content analysis process. Journal of Advanced Nursing, 62(1), 107-115.

Falagas, M. E., Pitsouni, E. I., Malietzis, G. A., \& Pappas, G. (2008). Comparison of PubMed, Scopus, Web of Science, and Google Scholar: Strengths and weaknesses. The FASEB Journal, 22, 338-342. https://doi.org/10.1096/fj.07-94921sf.

Ferber, M. A. (1986). Citations: Are they an objective measure of scholarly merit? Signs, 11, 381-389.

Godin, B. (2006). On the origins of bibliometrics. Scientometrics, 68, 109-133. https://doi.org/10.1007/ s11192-006-0086-0.

Goodman, G. S., \& Reed, R. S. (1986). Age differences in eyewitness testimony. Law and Human Behavior, 10(4), 317.

Graham, S. (1992). "Most of the subjects were White and middle class": Trends in published research on African Americans. American Psychologist, 47, 629-639.

Green, E., \& Heilbrun, K. (2014). Wrightsman's psychology and the legal system (8th ed.). Wadsworth: Cengage Learning.

Grisso, T. (1991). A developmental history of the American psychology-Law society. Law and Human Behavior, 15, 213-231. https://doi.org/10.1007/bf01061710.

Grisso, T., \& Appelbaum, P. S. (1995). The MacArthur Treatment Competence Study. III: Abilities of Patients to consent to psychiatric and medical treatments. Law and Human Behavior, 19(2), 149-174. 
Grisso, T., Steinberg, L., Woolard, J., Cauffman, E., Scott, E., Graham, S., et al. (2003). Juveniles' competence to stand trial: A comparison of adolescents' and adults' capacities as trial defendants. Law and Human Behavior, 27(4), 333.

Haney, C. (1980). Psychology and legal change: On the limits of a factual jurisprudence. Law and Human Behavior, 4, 147-199. https://doi.org/10.1007/bf01040317.

Haney, C. (1993). Psychology and legal change: The impact of a decade. Law and Human Behavior, 17, 371398. https://doi.org/10.1007/bf01044374.

Hanson, R. K., \& Thornton, D. (2000). Improving risk assessments for sex offenders: A comparison of three actuarial scales. Law and Human Behavior, 24, 119-136. https://doi.org/10.1023/a:1005482 921333.

Harris, G. T., Rice, M. E., \& Cormier, C. A. (1991). Psychopathy and violent recidivism. Law and Human Behavior, 15(6), 625.

Haslam, N., Ban, L., Kaufmann, L., Loughnan, S., Peters, K., Whelan, J., et al. (2008). What makes an article influential? Predicting impact in social and personality psychology. Scientometrics, 76, 169-185. https://doi.org/10.1007/s11192-007-1892-8.

Haslam, N., \& Koval, P. (2010). Predicting long-term citation impact of articles in social and personality psychology. Psychological Reports, 106, 891-900. https://doi.org/10.2466/pr0.106.3.891-900.

Helmreich, R. L., Spence, J. T., Beane, W. E., Lucker, G. W., \& Matthews, K. A. (1980). Making it in academic psychology: Demographic and personality correlates of attainment. Journal of Personality and Social Psychology, 39, 896-908.

Hérubel, J. P. V., Diodato, V., \& Sellen, M. K. (1999). Historical bibliometrics: Its purpose and significance to the history of disciplines. Libraries \& Culture, 34, 380-388.

Hsieh, H., \& Shannon, S. E. (2005). Three approaches to qualitative content analysis. Qualitative Health Research, 15, 1277-1288.

Hudson, J. (2007). Be known by the company you keep: Citations-Quality or chance? Scientometrics, 71, 231-238. https://doi.org/10.1007/s11192-007-1617-6.

Indiana University Center for Postsecondary Research (2015). The Carnegie classification of institutions of higher education. Bloomington, IN. Retrieved March 25, 2016, from http://carnegieclassifications .iu.edu/.

Kassin, S. M., Drizin, S. A., Grisso, T., Gudjonsson, G. H., Leo, R. A., \& Redlich, A. D. (2010). Policeinduced confessions: Risk factors and recommendations. Law and Human Behavior, 34, 3-38. https://doi.org/10.1007/s10979-009-9188-6.

Kilpatrick, D. G. (2000). Definitions of public policy and the law. Retrieved from the National Violence Against Women Prevention Research Center Web site https://mainweb-v.musc.edu/vawprevention/ policy/definition.shtml.

Kim, J. N., Park, S. C., Yoo, S. W., \& Shen, H. (2010). Mapping health communication scholarship: Breadth, depth, and agenda of published research in Health Communication. Health Communication, 25, 487503. https://doi.org/10.1080/10410236.2010.507160.

Kliegl, R., \& Bates, D. (2010). International collaboration in psychology is on the rise. Scientometrics, 87, 149-158. https://doi.org/10.1007/s11192-010-0299-0.

Kovera, M. B. (2013a). Law and human behavior update. American Psychology Law Society: Summer 2013 News. Retrieved April 24, 2016, from http://www.apadivisions.org/division-41/publications/ newsletters/news/2013/07/issue.pdf. 
Kovera, M. B. (2013b). Law and human behavior update. American Psychology Law Society: Winter 2013 News. Retrieved April 24, 2016, from http:/www.apadivisions.org/division-41/publications/newsletters/ news/2013/01-issue.pdf.

Kovera, M. B. (2015, July). Law and human behavior: Journal update. AP-LS News. Retrieved April 13, 2016, from http://www.apadivisions.org/division-41/publications/newsletters/news/2015/07/journal update.aspx.

Landis, J. R., \& Koch, G. G. (1977). The measurement of observer agreement for categorical data. Biometrics, 33, 159-174. https://doi.org/10.2307/2529310.

Leimu, R., \& Koricheva, J. (2005). What determines the citation frequency of ecological papers? Trends in Ecology E Evolution, 20, 28-32. https://doi.org/10.1016/j.tree.2004.10.010.

Leistico, A. M. R., Salekin, R. T., DeCoster, J., \& Rogers, R. (2008). A large-scale meta-analysis relating the Hare measures of psychopathy to antisocial conduct. Law and Human Behavior, 32(1), 28-45.

Levesque, R. J. R. (2007). The ethnicity of adolescent research. Journal of Youth Adolescence, 36, 375-389.

Lewison, G., \& Hartley, J. (2005). What's in a title? Numbers of words and the presence of colons. Scientometrics, 63, 341-356. https://doi.org/10.1007/s11192-005-0216-0.

Loftus, E. F., Loftus, G. R., \& Messo, J. (1987). Some facts about “weapon focus.” Law and Human Behavior, 11(1), 55.

Mayring, P. (2000). Qualitative content analysis. Forum Qualitative Sozialforschung/Forum Qualitative Social Research, 1. Retrieved 16 Feb 2018 from http://www.qualitative-research.net/fqs-texte/2-00/2-00mayring-e.htm.

McCann, L. I., Ebert, A. R., Timmins, R. R., \& Thompson, A. E. (2017). Changes in author, editor, and reviewer genders over 42 years in teaching of psychology. Teaching of Psychology, 44, 24-245. https://doi.org/10.1177/0098628317712748.

Meissner, C. A., \& Brigham, J. C. (2001). Thirty years of investigating the own-race bias in memory for faces: A meta-analytic review. Psychology, Public Policy, and Law, 7, 3-35. https://doi.org/10.1037/1076 8971.7.1.3.

Monahan, J., \& Loftus, E. F. (1982). The psychology of law. Annual Review of Psychology, 33, 441-475. https://doi.org/10.1146/annurev.ps.33.020182.002301.

Moore, L. R., \& Finn, P. E. (1986). Forensic psychology: An empirical review of experimental research. Journal of Clinical Psychology, 42, 675-679. https://doi.org/10.1002/1097-4679.

Münsterberg, H. (1908). On the witness stand: Essays on psychology and crime. New York: Doubleday, Page, $\&$ Co.

Ogloff, J. R. P. (2000). Two steps forward and one step backward: The law and psychology movement(s) in the 20th century. Law and Human Behavior, 24, 457-483. https://doi.org/10.1023/a:1005596414203.

Porter, C. L., Christian, L., \& Poling, A. (2003). Participation of women as authors and editors in journals concerned with mental retardation and related topics. Mental Retardation, 41, 1-6. https://doi.org/10.1352/ 0047-6765.

Rice, M. E., \& Harris, G. T. (1997). Cross-validation and extension of the Violence Risk Appraisal Guide for child molesters and rapists. Law and Human Behavior, 21(2), 231.

Rice, M. E., \& Harris, G. T. (2005). Comparing effect sizes in follow-up studies: ROC Area, Cohen's d, and r. Law and Human Behavior, 29(5), 615.

Rice, M. E., Harris, G. T., \& Cormier, C. A. (1992). An evaluation of a maximum security therapeutic community for psychopaths and other mentally disordered offenders. Law and Human Behavior, 16(4), 399. 
Roesch, R. (1990). From the editor. Law and Human Behavior, 14, 1-3. https://doi.org/10.1007/bf010 55785.

Saks, M. J. (1986). The law does not live by eyewitness testimony alone. Law and Human Behavior, 10, 279_ 280. https://doi.org/10.1007/bf01047341.

Seagrave, D., \& Grisso, T. (2002). Adolescent development and the measurement of juvenile psychopathy. Law and Human Behavior, 26(2), 219.

Slovic, P., Monahan, J., \& MacGregor, D. G. (2000). Violence risk assessment and risk communication: The effects of using actual cases, providing instruction, and employing probability versus frequency formats. Law and Human Behavior, 24(3), 271.

Small, M. A. (1993). Legal psychology and therapeutic jurisprudence. St. Louis University Law Journal, 37, 675-698.

Steblay, N. M. (1992). A meta-analytic review of the weapon focus effect. Law and Human Behavior, 16, 413-424. https://doi.org/10.1007/BF02352267.

Steinberg, L., \& Cauffman, E. (1996). Maturity of judgment in adolescence: Psychosocial factors in adolescent decision making. Law and Human Behavior, 20(3), 249.

Sternberg, R. J., \& Gordeeva, T. (1996). The anatomy of impact: What makes an article influential? Psychological Science, 7, 69-75. https://doi.org/10.1111/j.1467-9280.1996.tb00332.x.

Stewart, J. (1983). Achievement and ascriptive processes in the recognition of scientific articles. Social Forces, 62, 166-189. https://doi.org/10.2307/2578354.

Studebaker, C. A., Robbennolt, J. K., Penrod, S. D., Pathak-Sharma, M. K., Groscup, J. L., \& Devenport, J. L. (2002). Studying pretrial publicity effects: New methods for improving ecological validity and testing external validity. Law and Human Behavior, 26, 19-41. https://doi.org/10.1023/a:1013877108082.

Tapp, J. L. (1976). Psychology and the law: An overture. Annual Review of Psychology, 27, 359-404. https://doi.org/10.1146/annurev.ps.27.020176.002043.

Tarasoff v. Regents of the University of California, 17 Cal.3d 425, 551 P.2d 334, 131 Cal. Rptr. 14, (Cal. 1976).

Vaccaro, T. P., \& Hogan, J. D. (2004). The origins of forensic psychology in America: Hugo Munsterberg on the witness stand. New York State Psychologist, 16, 14-17.

Walia, P. K., \& Kaur, M. (2012). Content Analysis of Journal Literature published from UK and USA. Library Philosophy E Practice. Retrieved from http://digitalcommons.unl.edu/libphilprac/833/.

Wells, G. L., Small, M., Penrod, S., Malpass, R. S., Fulero, S. M., \& Brimacombe, C. E. (1998). Eyewitness identification procedures: Recommendations for lineups and photospreads. Law and Human Behavior, 22, 603-647. https://doi.org/10.1023/a:1025750605807.

West, M. S., \& Curtis, J. W. (2006). AAUP faculty gender equity indicators 2006 (p. 85). Washington, DC: American Association of University Professors. 